\title{
Article \\ Hydrological Modeling in Agricultural Intensive Watershed: The Case of Upper East Fork White River, USA
}

\author{
George Bariamis*(D) and Evangelos Baltas \\ Department of Water Resources \& Environmental Engineering, School of Civil Engineering, National Technical \\ University of Athens, Str. Iroon Politexniou 9, 15780 Zografou, Greece; baltas@chi.civil.ntua.gr \\ * Correspondence: bariamis@mail.ntua.gr
}

check for updates

Citation: Bariamis, G.; Baltas, E. Hydrological Modeling in Agricultural Intensive Watershed: The Case of Upper East Fork White River, USA. Hydrology 2021, 8, 137. https://doi.org/10.3390/ hydrology 8030137

Academic Editor: Giorgio Baiamonte

Received: 20 July 2021

Accepted: 7 September 2021

Published: 10 September 2021

Publisher's Note: MDPI stays neutral with regard to jurisdictional claims in published maps and institutional affiliations.

Copyright: (C) 2021 by the authors. Licensee MDPI, Basel, Switzerland. This article is an open access article distributed under the terms and conditions of the Creative Commons Attribution (CC BY) license (https:// creativecommons.org/licenses/by/ $4.0 /)$.

\begin{abstract}
Identifying the core hydrological processes of catchments is a critical step for operative hydrological modeling. This study attempts to assess the long-term alterations in streamflow in three adjacent catchments of Upper East Fork White River, Indiana USA, by employing the SWAT hydrological model. The model simulations are spanning from 1980 up to 2015 and distributed in three configurations periods to identify monthly alterations in streamflow. For this purpose, water abstraction, land use, tillage, and agricultural field drainage practices have been incorporated in the model to provide accurate data input. The model setup also integrates spatially disaggregated sectorial water use data from surface and groundwater resources integrating the significant increases of water abstractions mainly for agricultural and public water supply purposes. The land cover of the study area is governed by rotating crops, while agricultural practices and tile drainage are crucial model parameters affecting the regional hydrological balance. Streamflow prediction is based on the SUFI-2 algorithm and the SWAT-CUP interface has been used for the monthly calibration and validation phases of the model. The evaluation of model simulations indicate a progressively sufficient hydrological model setup for all configuration periods with NSE $(0.87,0.88$, and 0.88$)$ and PBIAS (14\%, $-7 \%$, and $-2.8 \%)$ model evaluation values at the Seymour outlet. Surface runoff/precipitation as well as percolation/precipitation ratios have been used as indicators to identify trends to wetter conditions. Model outputs for the upstream areas, are successful predictions for streamflow assessment studies to test future implications of land cover and climate change.
\end{abstract}

Keywords: hydrological modeling; streamflow; water balance; SWAT

\section{Introduction}

Growing population is expected to reach 10.9 billion by 2100 [1]. As a result, living standards and dietary lifestyles are progressively change in many regions around the world exerting even more pressures to the global food production system. Agricultural products are also used in the livestock and aquaculture industries increasing even more the global competition on water resources. Currently, agriculture uses $70-80 \%$ of global water resources to produce the necessary quantities ensuring food security in the supply chain [2]. In USA, agriculture is a key economic sector consuming $40 \%$ of the total water use in the country [3]. Key agricultural products are cultivated in several farming belts where the climate conditions are favorable for improved crop yields [4]. Corn and soybean are two of the most cultivated products in upper Mississippi River where intensive agriculture and crop rotation schemes are being practiced for more than a century. An area as large as the Corn Belt is subjected to changes in crop patterns, areal coverage, harvested lands and crop yields affected by the agricultural practices as well as by the climate conditions. A recent study estimated the crop rotation corn-soybean pattern is extending over the $70 \%$ of the Corn Belt area [5].

The state of Indiana is one of the key producer states of agricultural and livestock products in the Corn Belt region, centering a critical part of its economy and employment [6]. 
During the last decades corn and soybean have been significantly increased by $133 \%$ ( $80 \mathrm{bu} /$ acre to $187 \mathrm{bu} / \mathrm{acre}$ ) and by $93 \%$ (30 bu/acre to $58 \mathrm{bu} /$ acre) respectively [7].

The intensive agricultural development activities in the catchments' areas require consistent monitoring in key hydrologic parameters which affect the overall quality and quantity of the crop yields in the region like precipitation, temperature, soil properties, plantation, harvesting period, etc. Furthermore, the effective cultivation of highly valuable crops requires soil preparation during the early weeks of spring, as well as the application of pesticides and additional nutrients to ensure high yields [8,9].

Considering the soil preparation in the region, tile drainage is one of the most common practice which ensures the proper soil nutrients concentrations as well as moisture levels for a proper growing season. The installation of such subsurface tile drainage systems was a significant infrastructure investment in the region, which consequently enriched the soil with air by removing excess water and transforming wetland regions into highly nutrient content valleys for agricultural development [10].

Hydromorphological pressures [11], over-fertilization, short-term land use management $[12,13]$ are some serious problems in intensive agricultural areas, resulting in the collapse of surface and groundwater resources and consequently in the deterioration of ecosystem and their services [14,15]. It is well known that many of the agricultural practices applied in the upstream regions of the Mississippi River are the key drivers for serious impacts in the downstream riparian, coastal, and sea ecosystems in the Gulf of Mexico (eutrophication, chronic, and seasonal hypoxia) [16-19].

As a result of the extensive plowing and overall land use change dynamics over the years, with urbanization and agricultural areas expansion rates at high levels [20], soil structure is greatly unsettled, resulting in increased erosion risk and sediment transport phenomena. More specifically, sediment (suspended and wash load) is the primary mean of pollutant transport in the downstream areas which pose not only geomorphological degradation [21] but also risks for ecosystems status, issues which have to be considered by the current and future management practices applied by river basins committees and authorities [22]. The future of agriculture has to face considerable rise in food demand while trying to decrease its global footprint on natural resources [23].

Model-based methods for hydrological modeling are usually time consuming and require extensive time series of several water related parameters, therefore observationbased methods have been developed to provide quite accurate and early estimates of the human or natural influence on hydrological deficits/droughts [24]. Pair catchment analysis by using unsteady water balance equation and double mass curve techniques, can effectively separate climate change effects from the watershed disturbance (e.g., seasonal effects of forest coverage in hydrological drought). However, some of the limitations of such approaches are to find suitable catchment pairs with long-time series of available data on the pre-disturbance period, and relevant climate, land use characteristics along with detailed physical properties of the watersheds [25].

Hydrological modeling and computational techniques in hydrology have been offered very important advancements the last years due to the constant integration of more accurate algorithmic routines, predicting several hydrological cycle components with remarkable accuracy, as well as in the significant increase of computational power [26]. However, hydrological models are heavily dependent on rainfall observations which must capture accurate precipitation patterns and trends (in case of climate change impacts studies) to effectively simulate the water cycle, while climate/landscape models require further development to better describe spatial scale, magnitude, accuracy, and complexity issues [27]. Data inputs are the primary source of information which is used in the calibration and validation phases which cover a wide range of typology (from ground-based monitoring stations to satellite collected data) [28,29].

As the hydrological models principally attempt to provide the best available estimates of water-land-soil dynamics and regime in study areas simulated, there are a lot of intermediate preparatory steps, decisions and actions made by their operators to provide 
accurate simulations and targeted outputs. Model results are providing valuable feedback in assessing the surface/groundwater links [30], improvement of management practices under different scenarios [31-33], future projections for coupled land use-climate change impact assessments [34-36] and contribution to large scale modeling [37-41].

Models' applications have been extensively used in either local, regional or even continental scale simulations, where the quantitative and qualitative assessment can provide important conclusions for effective water management [42-46]. Hydrological models outputs have evolved to the level that they can provide to decision makers and policy planners the necessary inputs to protect the environment and ensure water security by the application of best management practices varying from focused sectorial measures of sustainable water use to emissions regulations in order to protect water quality and all dependent ecosystems' chain [47-50]. There is a need for continuous streamlined and monitoring programs for the anthropogenic and natural pressures on water resources based on the principles of collaborative adaptive management. Such approaches integrate experiences and the collective perspectives of managers, stakeholders and scientists in a way which minimizes the sources of uncertainties while supporting informed management decisions in complex and competitive watersheds [51].

Responding to the need for transparent and accessible data inputs and interpretation of model outcomes, the UN Statistics Division has been working in the last few decades with international organizations as well as along with environmental and economic institutes in environmental accounting approaches [52]. Environmental accounting provides the standardization of environmental and economic information in a way to identify their interactions with the anthropogenic socioeconomic environment, which as a process can be defined as the starting point of future long-term planning of the utilization of natural resources. Environmental accounting methodologies have been applied in the domains of water, land, forestry, ecosystems, and energy [53-55].

\section{Materials and Methods}

\subsection{Watershed Description}

The study area of headwaters of Upper East Fork White River (UEFWR) consists of three adjacent catchments in the headwaters of the Patoka White River, a tributary of the Wabash River in the state of Indiana, USA. They cover an area of approximately $5700 \mathrm{~km}^{2}$. The three catchments are the cataloging units of Driftwood (HUC8 - 05120204), Flatrock-Haw (HUC8 - 05120205) and the Upper East Fork White (HUC8 - 05120206) based on the USGS Watershed Boundary Dataset [56]. The study area is drained in the USGS monitoring location 03365500, at East Fork White River at Seymour, Indiana, $95 \mathrm{~km}$ southeast from the State's capital City of Indianapolis. The study area is delineated within the boundaries of Bartholomew, Marion, Hancock, Henry, Johnson, Shelby, Rush, Decatur, Jackson, and Jennings counties of Indiana where a population of more than 440,000 people reside (Figure 1a).

The elevation of the watershed ranges from 158 to $358 \mathrm{~m}$ with an average value of $258 \mathrm{~m}$ as shown in Figure 1b. Elevation data have been acquired from the NASA SRTM program [57]. The soil characteristics have been integrated based on the STATSGO soil dataset, integrating 19 different soil types [58,59]. The relief is majorly formed in light slopes (average slope $2 \%$ ) forming flatlands ideal for extensive agricultural development. The study area was grouped into three slope classes: (a) $<2 \%$, (b) $2-5 \%$, and (c) $>5 \%$ as shown in Figure 1c.

Within the study area, there were used nine weather and four streamflow stations. The average elevation of the weather stations is $238 \mathrm{~m}$, while climate normal in the Shelbyville station for the 1981-2010 period are for total average precipitation $1106 \mathrm{~mm} /$ year ( $\mathrm{min} / \mathrm{max}: 60 / 134 \mathrm{~mm}$ ) and for the annual average temperature $6.3^{\circ} \mathrm{C}\left(\mathrm{min} / \mathrm{max}:-4.5 / 17.6^{\circ} \mathrm{C}\right)[60]$. The weather stations (for precipitation and $\mathrm{min} / \mathrm{max}$ temperatures) included in the databases were acquired from the NOAA database [61] and are in Columbus (USC00121747), Greenfield (USC00123527), Greensburg (USC00123547), New Castle (USC00126164), Rushville (USC00127646), Seymour 
(USC00127935), Shelbyville Sewage plant (USC00127999), Indianapolis International Airport (USW00093819), and Martinsville (USC00125407).

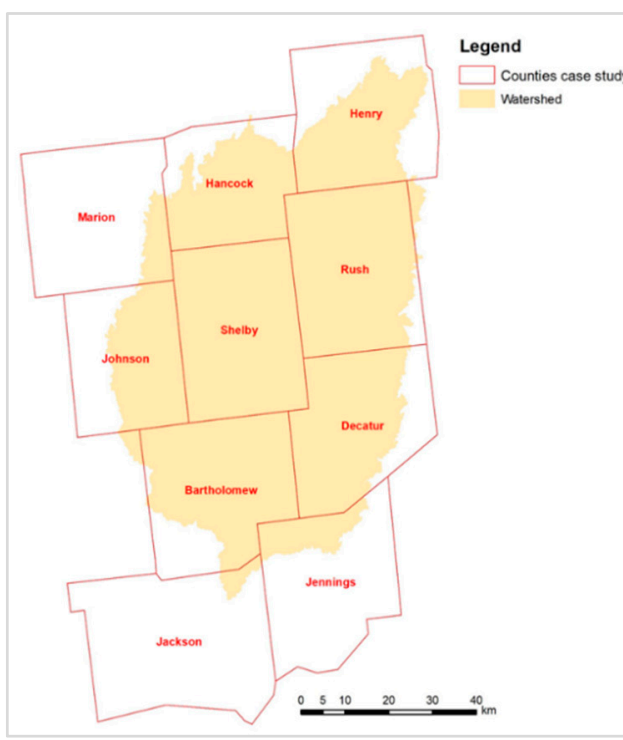

(a)

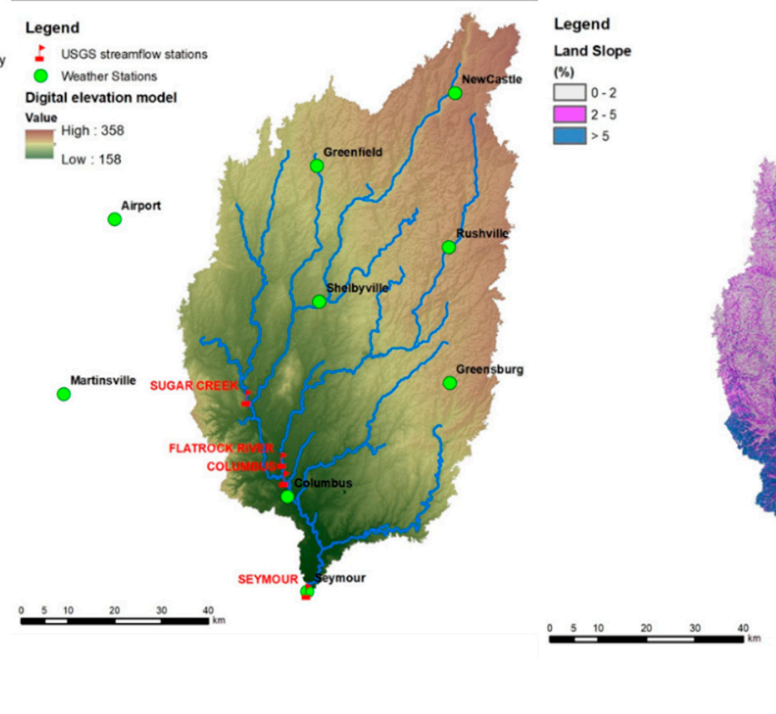

(b)

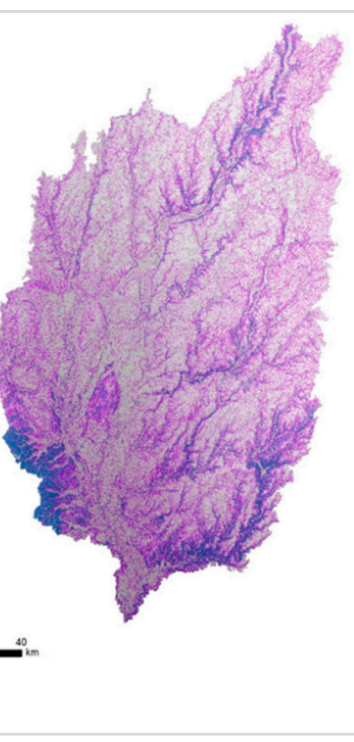

(c)

Figure 1. Study area with counties delineation (a), digital elevation model with weather and streamflow stations (b), slope distribution (c).

\subsection{Land Use}

In order to successfully perform long term hydrological evaluation via modeling, necessary data inputs had to be collected and curated prior to their integration in the respective SWAT working database. One of the major components affecting the overall rainfall-runoff regime in hydrological models is the land cover status. In our case study, we organized the modeling period into three configuration periods in an attempt to adequately capture the dynamic change of each of the water balance components without adding unnecessary computational burden. The above periods refer to the following years; $\mathrm{C}_{1}$ (1980-1992), $C_{2}$ (1993-2002), and $C_{3}$ (2003-2015). For this purpose, three land cover and use instances (NLCD version of 1992, USDA CropScape versions of 2001 and 2011) have been acquired and integrated in each of the model configuration as shown in Figure 2b [62-64].

The distribution of land use types describes a relative stable land use conditions over the last 30 years with the agriculture to be the dominant one [65-67]. In detail, corn and soyabean cultivated in crop rotation pattern, occupy $65 \%$ of the total area. The land cover types balance for the latest year of the assessment in 2011 is: 65\% agriculture, $14 \%$ forest, $11 \%$ pastures, $10 \%$ urban development, and 1\% water surfaces [67]. During the period 1980-2015 in the basin there was a substantial increase in the developed areas (from 3\% to $10 \%$ ) and in forested areas (from $9 \%$ to $14 \%$ ), while pasture areas cover was decreased (from $20 \%$ down to $11 \%$ ) as shown in Figure 2a.

\subsection{Streamflow Data}

The streamflow data have been acquired from the USGS National Water Information System (NWIS) at four gauging sites; Starting from the headwaters Sugar Creek (USGS STATID: 03362500) draining 18\% of the watershed subbasins, Flatrock River at Columbus (USGS STATID: 03363900) draining 23\%, East Fork White River at Columbus (USGS STATID: 03364000) draining 78\% of the area and Seymour (USGS STATID: 03365500) which is the watershed's outlet. The monthly average summaries of the streamflow stations for each of the configuration periods are presented in Figure 3. 


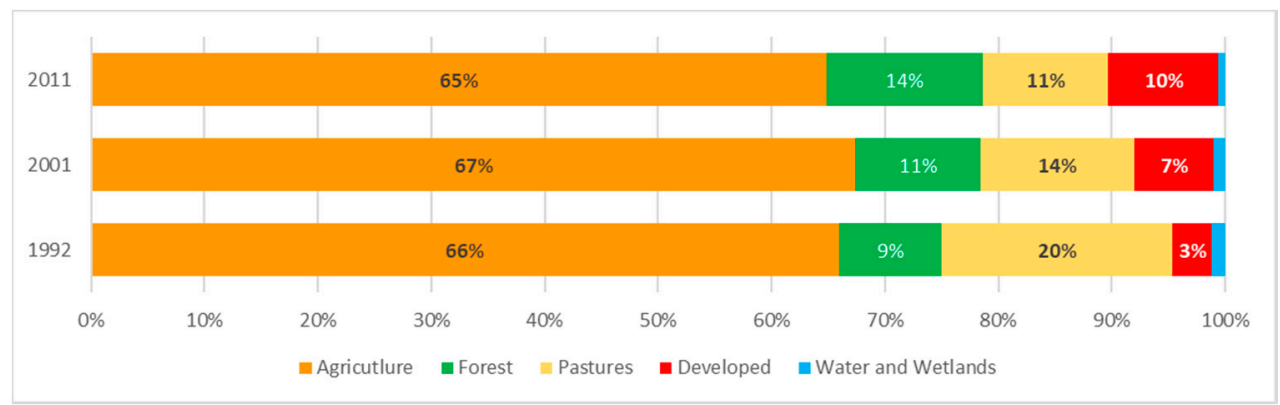

(a)
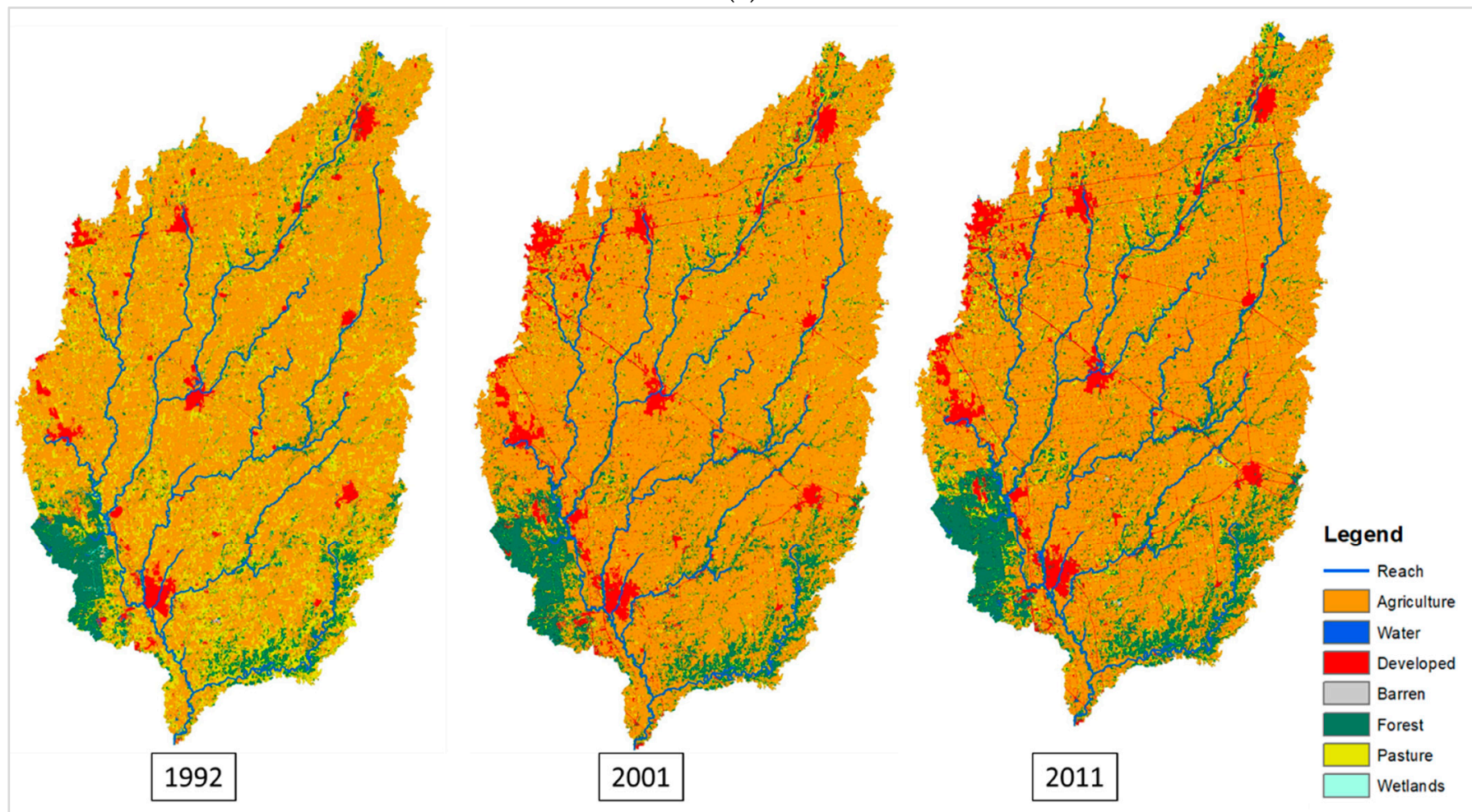

(b)

Figure 2. Land use distribution in the UEFWR basins (a) and land use maps integrated in the databases for each of the configuration periods: $C_{1}-1992, C_{2}-2001$, and $C_{3}-2011(b)$.

\subsection{SWAT Model}

The SWAT model is a river basin scale model developed by USDA Agricultural Research Service [68]. Its main characteristics are that it is physically based, of continuous simulation, semi distributed, utilizing already available data inputs in a computationally efficient way for simulations which can span for several decades and large study areas [69].

The land phase of the hydrological cycle in SWAT is described by the Equation (1) below:

$$
S W_{t}=S W_{0}+\sum_{i=1}^{t}\left(R_{\text {day }}-Q_{\text {surf }}-E_{a}-W_{\text {seep }}-Q_{g w}\right)
$$

where, $S W_{t}$, is the final soil water content, $S W_{0}$ is the initial soil water content, $R_{d a y}$ is the amount of daily precipitation, $Q_{\text {surf }}$ is the amount of daily surface runoff, $E_{a}$ the daily actual evapotranspiration, $W_{\text {seep }}$ the groundwater recharge to the unsaturated (vadose) zone, and $Q_{g w}$ the daily groundwater return flow to the stream, in $\mathrm{mm}$ [69].

It is a model which is continually upgraded and expanded in critical water related processes throughout the years [68,70-72]. The SWAT model is organizing the watershed 
in smaller partitions with unique land cover, soil and management arrangements. These areas are the hydrologic response units (HRUs) where the land and routing phases of the hydrologic cycle are modelled to provide accurate predictions. The land surface of the hydrologic cycle includes climate parameters, natural hydrologic processes, land cover/plant growth, erosion, nutrients, pesticides, and other management practices occurring in each of the HRUs of the model. A recent release of the model (SWAT2012 rev. 681) was used and in combination with the ArcGIS (version 10.3) interface (ArcSWAT 2012.10.3.19) was used in this paper [73].
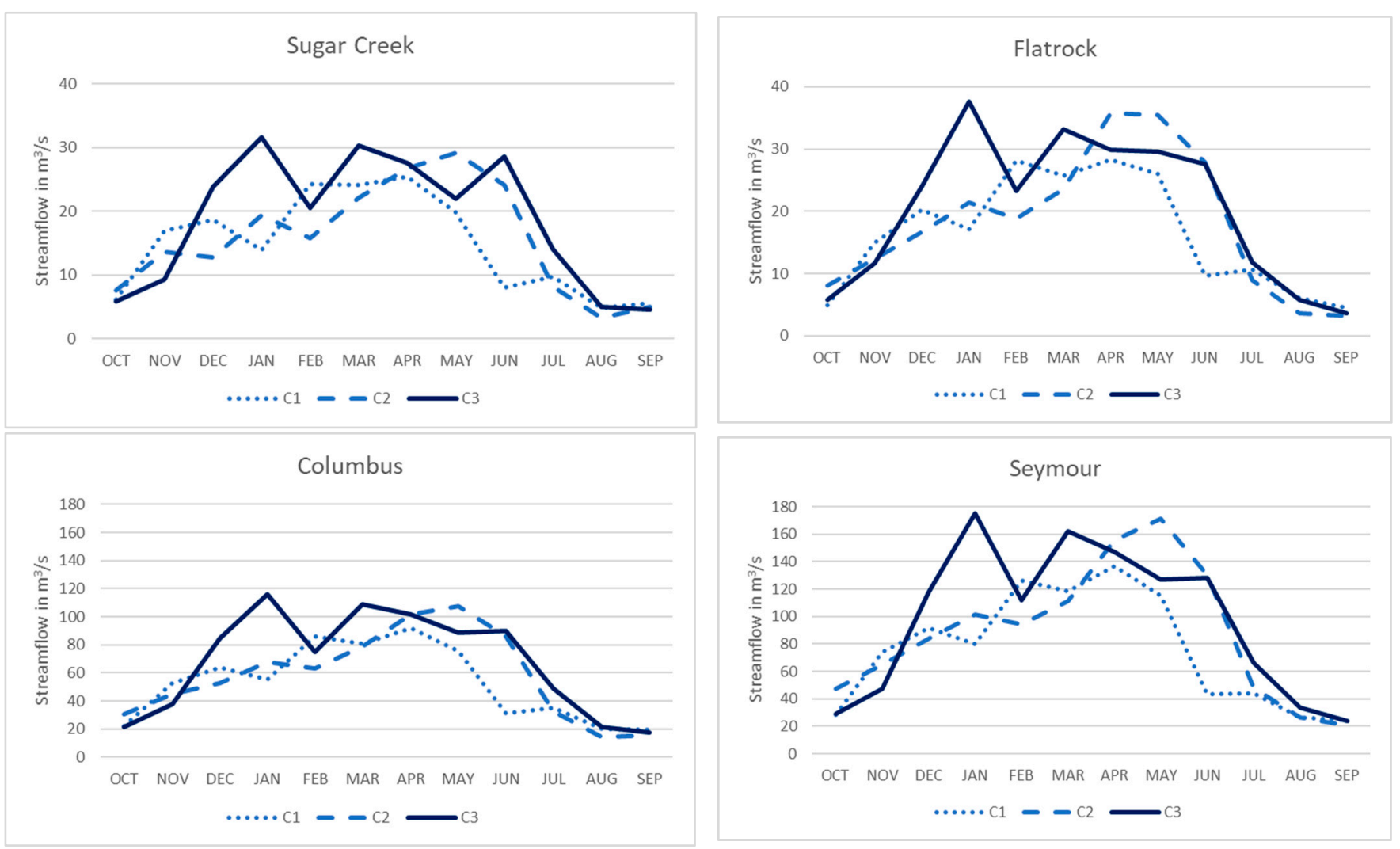

Figure 3. Monthly average streamflow (in $\mathrm{m}^{3} / \mathrm{s}$ ) in water years for the gauging stations distributed in the configuration periods.

\subsection{Agricultural Practices Data}

The case study area is one of the most productive in the state of Indiana in terms of agricultural yield. In the study area the crop rotating plantation of corns and soyabeans is being majorly applied [74,75]. Since this agricultural practice is being applied in two or three-year cycles, it has been integrated via the management operations module for better model functioning and water-land relations parameterization. This includes an April to October entire agricultural season with tillage operations, plantations and five-month growing seasons, fertilizer application, and final harvesting [76]. Based on USDA the UEFWR has somewhat poorly and moderately well natural soils drainage characteristics. Therefore, the tile drains were simulated with at $1200 \mathrm{~mm}$ depth, $24 \mathrm{~h}$ the time to drain a soil to field capacity, and $72 \mathrm{~h}$ the amount of time required to release water from a drain tile to a stream reach $[76,77]$. Tile drainage has been applied in agricultural corn and soyabean fields where slope is in the $0-2 \%$ range class.

\subsection{Water Abstraction}

Water removal from the environment plays a key role while elaborating with hydrological modeling, as it affects the overall water availability as well as from which water resource type (surface or groundwater), the respective volumes have been withdrawn. The case where detailed data collection on water abstractions can be available, it can serve the 
overall modeling purpose by affecting the respective components as well as supporting more detailed model outputs via improved calibration approach. In the case study area, the Indiana Department of Natural Resources (DNR) operates the Significant Water Withdrawal Facility (SWWF) database where facilities with a capability of abstracting more than 100,000 gallons of water a day (groundwater, surface water, or their combination) are being registered [78]. The UEFWR watershed is intersecting with seven Indiana counties where relative data were available; Bartholomew, Hancock, Henry, Johnson, Shelby, Rush, and Decatur. A spatial analysis has been conducted in order to select the number of facilities within each of the counties, and afterwards to integrate the water abstraction volumes in the SWAT database in the respective subbasins. This analysis also allowed to assess the type of surface or groundwater resource from where it was abstracted (Figure 4a), as well as for which servicing sector this water volumes have been used for (Figure $4 \mathrm{~b}$ ). As the SWWF volumes dataset was not available for the whole period due to technical reasons (size and complexity) the water abstraction data from 1980-2015 by USGS Water Use Data for the Nation program have been used [3,79-85]. This option was selected in order to support the modeling period in the three configuration periods. Based on our analysis the total annual water abstraction for each of the configuration periods are $C_{1}=45.2 \mathrm{hm}^{3}$, $C_{2}=62.5 \mathrm{hm}^{3}$, and for $C_{3}=57.5 \mathrm{hm}^{3}$. Starting from 1984 there was a significant increase of water withdrawal facilities from 158 up to 487 , while $90 \%$ of the facilities were pumping stations from groundwater (Figure 3). The pumping capacity has been climbed to an average $51 \mathrm{hm}^{3} /$ month in 2015 starting from $18 \mathrm{hm}^{3} /$ month in 1984 . As for the sectorial distribution of water abstracted $74 \%$ is being allocated for public water supply, $13 \%$ for industrial uses, and $12 \%$ for agricultural production. The water abstraction data have been integrated in the SWAT database (.wus table) on monthly average basis.

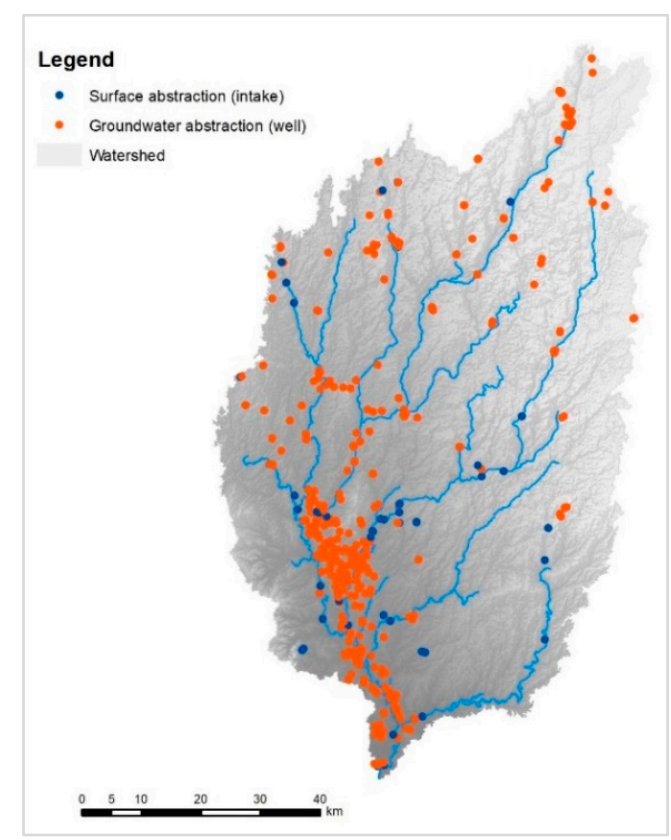

(a)

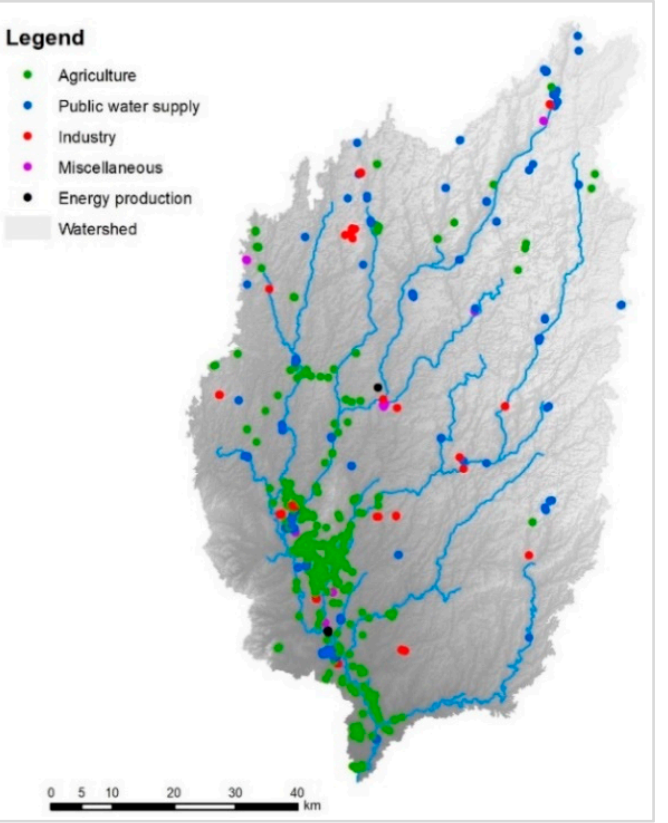

(b)

Figure 4. Water abstraction facilities (as of 2015) in the study area that significantly abstract water by source type (a) and by sector type (b).

\subsection{Calibration and Validation Approach}

The purpose of the calibration process is to optimize the performance of the model given the inherent modelling uncertainties already in place while trying to predict the function of each of the hydrological processes. The calibration approach followed in this study was focused on the routing phase of the hydrological cycle by mainly adjusting surface runoff and baseflow model components. 
The calibration/validation processes have been conducted in the locations of the four USGS gauging stations at Sugar Creek, Flatrock, Columbus, and the Seymour outlet. Sugar Creek and Flatrock upstream areas are considered hydrologically independent as no other evidence and data are known in case of significant water transfers between them or among other locations. Columbus is the station directly downstream of Flatrock, while Seymour in the outlet is affected by the upstream Columbus calibration process and from the remaining $12 \%$ of the ungauged area southeast of the UEFWR basin.

Each of the upstream drainage areas of the respective stations, have been parameterized and calibrated with the SWAT-CUP software [86], an interface which delivers significantly improved results by utilizing the Sequential Uncertainty Fitting algorithm (SUFI-2). Based on similar studies review utilizing SUFI-2 [49,87-90], eight sensitive streamflow related parameters have been selected to be optimized in order to provide improved streamflow calibration results. The selection of the list of calibrated parameters is based on a selection of the most sensitive streamflow related parameters [76,91-93].

The initial SCS runoff curve number (CN2.mgt) and available water capacity of the first soil layer (SOL_AWC(1).sol) have been optimized by relevant variation in the range of $[-20 \%,+20 \%]$, while baseflow alpha factor (ALPHA.BF.gw), groundwater delay (GW_DELAY.gw), threshold depth of water in the shallow aquifer for return flow (GWQMN.gw), groundwater re-evaporation coefficient (GW_REVAP.gw), deep aquifer percolation (RCHRG_DP.gw), and soil evaporation compensation factor (ESCO.hru) have been set to vary within a range of absolute values as shown in Table 1. For the snow parameters in the basins, a soft calibration approach has been selected by assigning minimum and maximum snow melt rate (SMFMX.bsn and SMFMN.bsn) to $1 \mathrm{~mm}$ of $\mathrm{H} 2 \mathrm{O} /{ }^{\circ} \mathrm{C}$-day and for the snow pack temperature lag factor to 0.4 (TIMP.bsn) [76]. At first, the Sugar Creek (seven upstream basins) and Flatrock (seven upstream basins) upstream regions have been calibrated, then Columbus (14 upstream basins) as the right after in the downstream route of the river, and in the end the Seymour outlet (14 upstream basins) as shown in Figure 5. In total, there were 42 basins that the respective parameters have been calibrated for a set of 500 simulations for each one of them. A set of consecutive years within each of the configuration periods have been used for warm-up ( $3 \mathrm{y})$, calibration ( $\geq 8 \mathrm{y}$ ) and for validation the last $3-4$ y of each of the configuration periods. Regarding the suspended sediment load data, there were not available for any of the configuration periods since their data collection in Seymour outlet ended in 1981.

Table 1. Optimized parameters with the SUFI-2 algorithm implemented in SWAT-CUP.

\begin{tabular}{ccc}
\hline SWAT Parameter & Physical Explanation & Range \\
\hline CN2 (.mgt) & $\begin{array}{c}\text { Initial SCS runoff curve number for } \\
\text { moisture condition II }\end{array}$ & {$[-20 \%,+20 \%]$} \\
SOL_AWC(1) $(. \mathrm{sol})$ & Available water capacity of first soil & {$[-20 \%,+20 \%]$} \\
ALPHA_BF $(. \mathrm{gw})$ & layer $(\mathrm{mm} / \mathrm{mm})$ & $0-1$ \\
GW_DELAY $(. \mathrm{gw})$ & Gaseflow alpha factor (days) & $0-300$ \\
GWQMN $(. \mathrm{gw})$ & Threshold depth of water in shallow & $0-300$ \\
GW_REVAP $(. \mathrm{gw})$ & aquifer for return flow $\left(\mathrm{mm} \mathrm{H}_{2} \mathrm{O}\right)$ & $0-0.2$ \\
RCHRG_DP $(. \mathrm{gw})$ & Groundwater "revap" coefficient & $0-0.5$ \\
ESCO $(. \mathrm{hru})$ & Deep aquifer percolation fraction & $0.7-1$ \\
\hline
\end{tabular}




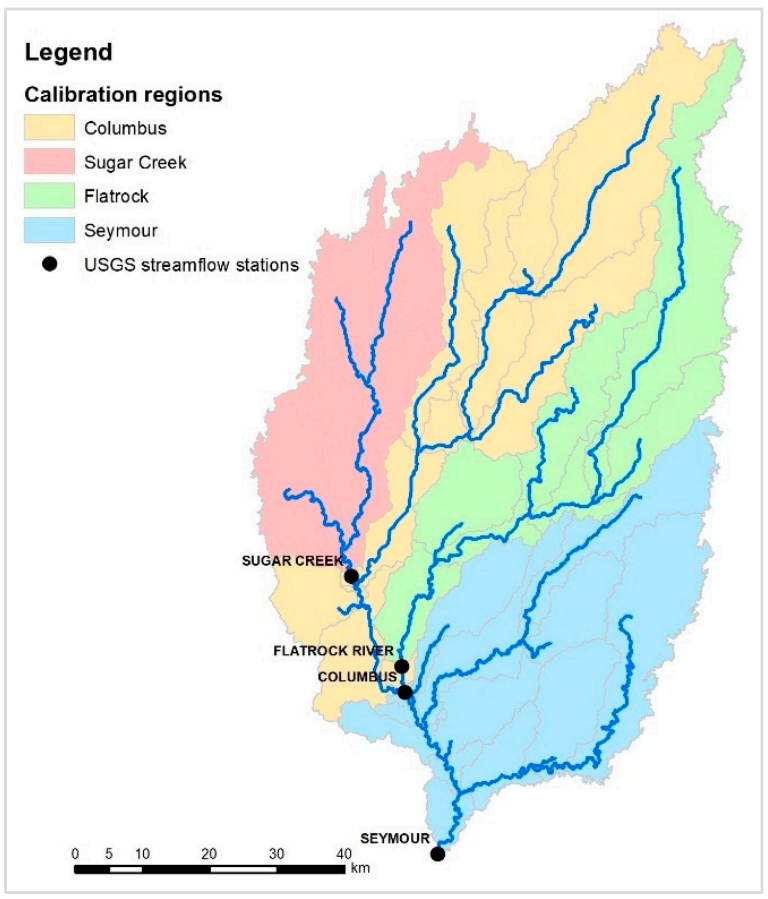

Figure 5. Delineation of the upstream areas, defined by the USGS gauging stations, where calibration phase has been implemented.

\section{Results}

\subsection{Streamflow Calibration Results}

As a result of the sequential parametric fitting, the new values of the parameters have been acquired, evaluating the calibration performance against measured streamflow in the four USGS monitoring sites, integrated in the SWAT databases, and run for the years of validation's evaluation. The performance of the model in each of the calibration and validation phases has been evaluated with the Nash-Sutcliffe (NSE) model efficiency coefficient [94], PBIAS, and coefficient of determination $\left(\mathrm{R}^{2}\right)$ based on the calibration and validation evaluation approach $[95,96]$ and results [91].

Based on $[95,97]$ the recommended evaluation criteria for recommended statistical performance for modelled flow as model outputs response on monthly scale and 'very good' indication are NSE $>0.8$, PBIAS $(\%)< \pm 5 \%$ and $\mathrm{R}^{2}>0.85$. The new parameters' ranges or absolute values are presented in the Table 2 below for the best simulation fit of SUFI-2 algorithm which was also was the basis to update SWAT model parameters used for the validation phase of this study.

The implementation of auto calibration with SUFI-2 algorithm has been successfully completed based on our approach to calibrate in four locations, in absence of other spatial datasets that could potentially support more detailed parameterization of the SWAT parameters. The evaluation of the calibration and validation results is presented in the Table 3 below for each of the stations and for every configuration period assessed. 
Table 2. Calibration results of the SUFI-2 algorithm for each of the three configuration periods and each of the stations' upstream drainage areas.

\begin{tabular}{|c|c|c|c|c|c|c|c|c|c|c|c|c|}
\hline & \multicolumn{4}{|c|}{$\mathrm{C}_{1}$} & \multicolumn{4}{|c|}{$\mathrm{C}_{2}$} & \multicolumn{4}{|c|}{$\mathrm{C}_{3}$} \\
\hline & Sugar Crk & Flatrock & Columbus & Seymour & Sugar Crk & Flatrock & Columbus & Seymour & Sugar Crk & Flatrock & Columbus & Seymour \\
\hline CN2.mgt & $-19.2 \%$ & $-6.5 \%$ & $1.6 \%$ & $-16.4 \%$ & $2.0 \%$ & $-2.0 \%$ & $-13.3 \%$ & $-16.4 \%$ & $2.3 \%$ & $1.6 \%$ & $-18.8 \%$ & $4.6 \%$ \\
\hline ALPHA_BF.gw & 0.06 & 0.06 & 0.06 & 0.65 & 0.81 & 0.16 & 0.06 & 0.65 & 0.97 & 0.06 & 0.71 & 0.93 \\
\hline RCHRC_DP.gw & 0.43 & 0.21 & 0.05 & 0.09 & 0.83 & 0.10 & 0.03 & 0.09 & 0.38 & 0.05 & 0.10 & 0.09 \\
\hline GW_DELAY & 12.74 & 20.70 & 20.70 & 22.50 & 14.25 & 56.10 & 32.70 & 22.50 & 9.90 & 20.70 & 38.70 & 18.90 \\
\hline GWQ̄MN.gw & 58.00 & 128.70 & 164.70 & 191.70 & 130.35 & 249.30 & 255.90 & 191.70 & 62.70 & 164.70 & 3.30 & 112.50 \\
\hline GW_REVAP.gw & 0.07 & 0.06 & 0.13 & 0.03 & 0.15 & 0.19 & 0.17 & 0.03 & 0.17 & 0.13 & 0.18 & 0.11 \\
\hline ESCO.hru & 0.99 & 0.83 & 0.90 & 0.98 & 0.98 & 0.70 & 0.93 & 0.98 & 0.98 & 0.90 & 0.74 & 0.99 \\
\hline SOL_AWC.sol & $-3.4 \%$ & $-16.4 \%$ & $8.4 \%$ & $-19.7 \%$ & $-13 \%$ & $-17 \%$ & $19.6 \%$ & $-19.7 \%$ & $-14.9 \%$ & $8.4 \%$ & $-7.3 \%$ & $-11.4 \%$ \\
\hline
\end{tabular}


Table 3. Streamflow calibration and validation results for each of the gauging stations and the respective configuration periods.

\begin{tabular}{|c|c|c|c|c|c|c|c|c|c|c|}
\hline \multicolumn{6}{|c|}{ Calibration } & \multicolumn{5}{|c|}{ Validation } \\
\hline & Station & $p$ & $\mathbf{R}^{2}$ & NSE & $\begin{array}{c}\text { PBIAS } \\
(\%)\end{array}$ & & Station & $\mathbf{R}^{2}$ & NSE & $\begin{array}{c}\text { PBIAS } \\
(\%)\end{array}$ \\
\hline \multirow{4}{*}{$\begin{array}{c}C_{1} \\
(1983- \\
1989)\end{array}$} & $\begin{array}{l}\text { Sugar } \\
\text { Crk }\end{array}$ & 0.39 & 0.66 & 0.63 & 13.5 & \multirow{4}{*}{$\begin{array}{c}C_{1} \\
(1990- \\
1992)\end{array}$} & $\begin{array}{l}\text { Sugar } \\
\text { Crk }\end{array}$ & 0.84 & 0.66 & 33.00 \\
\hline & Flatrock & 0.86 & 0.88 & 0.87 & 6.00 & & Flatrock & 0.84 & 0.82 & 14.00 \\
\hline & Columbus & 0.69 & 0.88 & 0.88 & 5.20 & & Columbus & 0.88 & 0.83 & 16.50 \\
\hline & Seymour & 0.46 & 0.89 & 0.88 & 9.20 & & Seymour & 0.90 & 0.87 & 14.50 \\
\hline \multirow{4}{*}{$\begin{array}{c}C_{2} \\
(1993- \\
1999)\end{array}$} & $\begin{array}{l}\text { Sugar } \\
\text { Crk }\end{array}$ & 0.73 & 0.92 & 0.89 & 15.30 & \multirow{4}{*}{$\begin{array}{c}C_{2} \\
(2000- \\
2002)\end{array}$} & $\begin{array}{l}\text { Sugar } \\
\text { Crk }\end{array}$ & 0.83 & 0.83 & -4.30 \\
\hline & Flatrock & 0.89 & 0.90 & 0.90 & -2.30 & & Flatrock & 0.82 & 0.54 & -40.20 \\
\hline & Columbus & 0.76 & 0.94 & 0.94 & 5.20 & & Columbus & 0.91 & 0.87 & -11.60 \\
\hline & Seymour & 0.69 & 0.94 & 0.92 & 7.70 & & Seymour & 0.89 & 0.88 & -6.90 \\
\hline \multirow{4}{*}{$\begin{array}{c}C_{3} \\
(2003- \\
2011)\end{array}$} & $\begin{array}{l}\text { Sugar } \\
\text { Crk }\end{array}$ & 0.71 & 0.88 & 0.88 & 1.00 & \multirow{4}{*}{$\begin{array}{c}C_{3} \\
(2012- \\
2015)\end{array}$} & $\begin{array}{c}\text { Sugar } \\
\text { Crk }\end{array}$ & 0.83 & 0.83 & 3.20 \\
\hline & Flatrock & 0.77 & 0.86 & 0.86 & 0.20 & & Flatrock & 0.85 & 0.65 & -13.40 \\
\hline & Columbus & 0.62 & 0.90 & 0.90 & 3.70 & & Columbus & 0.85 & 0.84 & 5.40 \\
\hline & Seymour & 0.53 & 0.90 & 0.88 & 6.50 & & Seymour & 0.89 & 0.88 & -2.80 \\
\hline \multicolumn{11}{|c|}{ Proposed ranges of model evaluation criteria } \\
\hline & & & $\mathrm{R}^{2}$ & NSE & $\begin{array}{c}\text { PBIAS } \\
(\%)\end{array}$ & & & & & \\
\hline & Satisfactory & & $0.7-0.8$ & $0.55-0.7$ & $\begin{array}{c} \pm(10- \\
15)\end{array}$ & & & & & \\
\hline & Good & & $0.8-0.85$ & $0.7-0.85$ & $\pm(3-10)$ & & & & & \\
\hline & Very good & & $0.85-1$ & $0.85-1$ & $\pm(0-3)$ & & & & & \\
\hline
\end{tabular}

Additionally, the model performance for wet (October-March) and dry (April-September) seasons are also presented in Table 4 . We used the recommended model performance measures for both calibration and validation phases for a SWAT set-up on monthly temporal resolution in an effort to minimize the uncertainties in ungauged parts of the UEFWR basin, especially for Flatrock and Columbus upstream basins [91,95]. For the first and second configuration periods $\left(C_{1}\right.$ and $\left.C_{2}\right)$, both coefficient of determination $\left(R^{2}\right)$ and Nash-Sutcliffe efficient results are satisfactory in Flatrock, Columbus, and Seymour outlet, while for the Sugar Creek, lower values of the evaluators were observed with a negligible trend of the model to underestimate the streamflow. In the calibration results of the third configuration period $\left(C_{3}\right)$, in all four stations the results are very satisfactory and withing the acceptable limits.

Table 4. Model performance for low (dry) and high (wet) flow seasons.

\begin{tabular}{cccccc}
\hline & & Sugar Crk & Flatrock & Columbus & Seymour \\
\hline \multirow{2}{*}{ Low flow } & NSE & 0.77 & 0.75 & 0.84 & 0.93 \\
season & PBIAS $(\%)$ & $14 \%$ & $-5 \%$ & $4 \%$ & $4 \%$ \\
& $\mathrm{R}^{2}$ & 0.69 & 0.87 & 0.88 & 0.88 \\
\hline \multirow{2}{*}{ High flow } & NSE & 0.87 & 0.92 & 0.94 & 0.94 \\
season & PBIAS $(\%)$ & $6 \%$ & $2 \%$ & $5 \%$ & $8 \%$ \\
& $\mathrm{R}^{2}$ & 0.73 & 0.93 & 0.91 & 0.94 \\
\hline
\end{tabular}

For the evaluation of the validation period, we observed satisfactory performance for $\mathrm{R}^{2}$ and NSE model evaluators in all periods for the outlet, while for C1 in Sugar Creek, in $\mathrm{C} 2$ and $\mathrm{C} 3$ in Flatrock we noted that model underestimated the streamflow presenting 
lower performance values. For the basin's outlet at Seymour, the validation results were $\mathrm{R}^{2}=0.89, \mathrm{NSE}=0.88$, and PBIAS $=-2.80 \%$ which were considered very satisfactory. The full time series of the modeling period is presented for each of the stations and covering both calibration and validation phases in Figure 6 below.
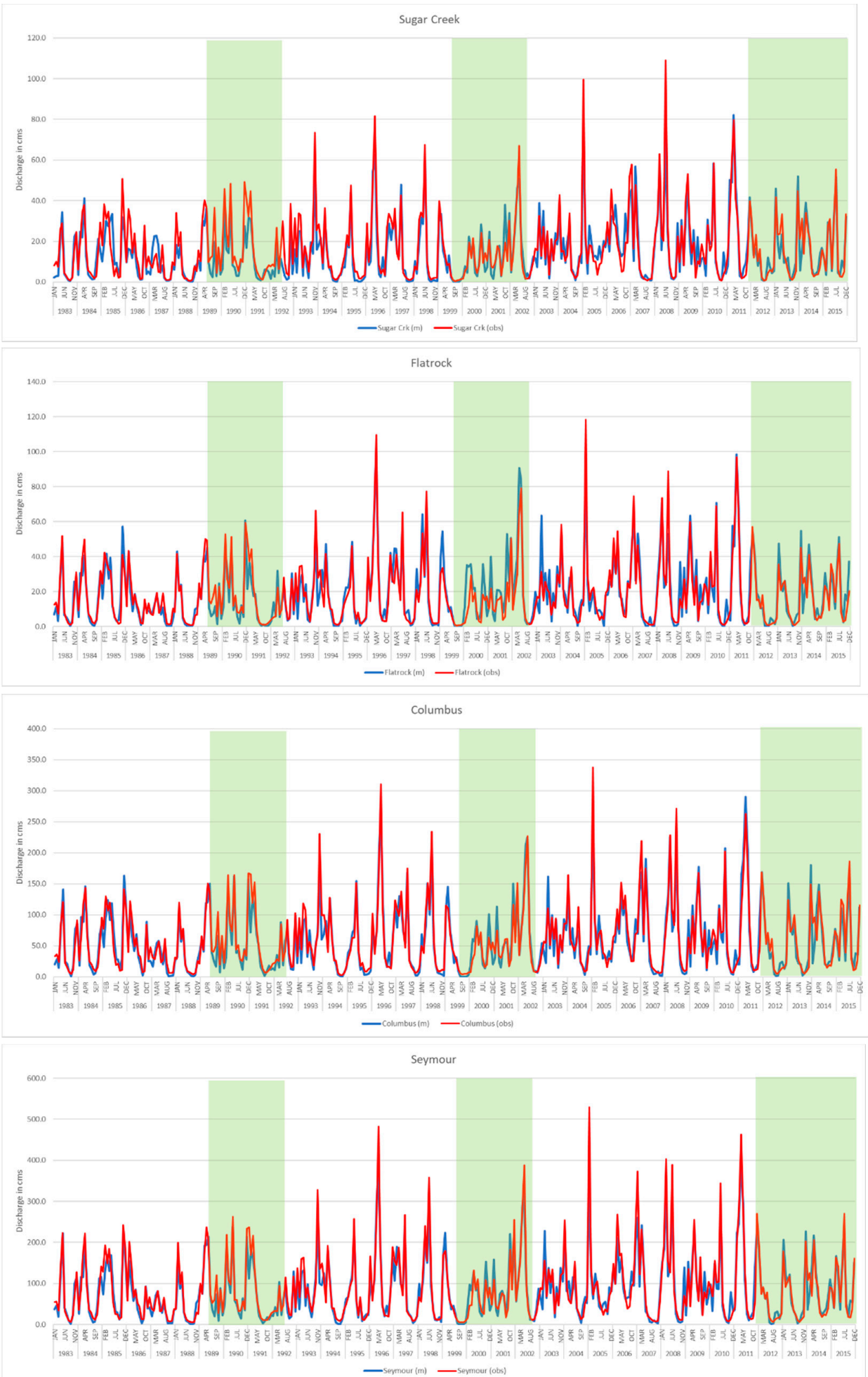

Figure 6. Monthly discharge (in $\mathrm{m}^{3} / \mathrm{s}$ ) timeseries of observed (red) and modeled (blue) outputs for Sugar Creek, Flatrock, Columbus, and Seymour (outlet) monitoring sites. With light green are highlighted the intermediate validation time range among the different configuration periods. 


\subsection{Precipitation-Snowmelt}

Based on the predominant climate conditions in the State of Indiana and in the study area, snowfall is characteristic element of the weather in the region greatly affecting the crop production (by defining level of soil conditions, proper for crop plantation) in each of the growing seasons, while providing increased spring/early summer seasonal streamflow from snowmelt.

Analyzing the model outputs for the precipitation/snowmelt balance, we observed that annual average snow melt accounted for an average $9 \%$ of precipitation for all configuration periods. In detail, the maximum average monthly snowmelt to precipitation ratio was $39 \%$ in $C_{1}, 47 \%$ in $C_{2}$, and $38 \%$ in $C_{3}$ period, which were all observed in February as shown in Figure 7.

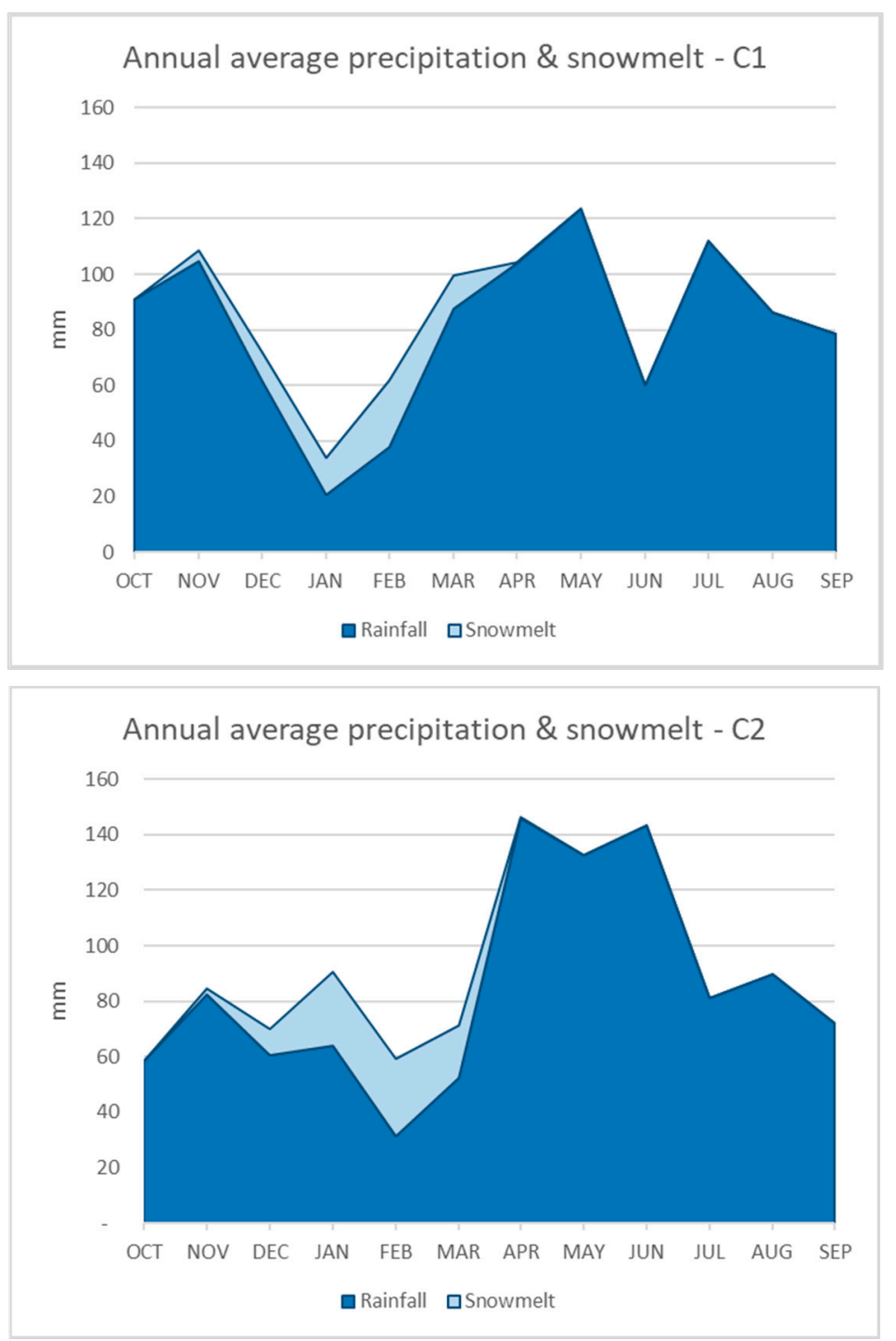

Figure 7. Cont. 


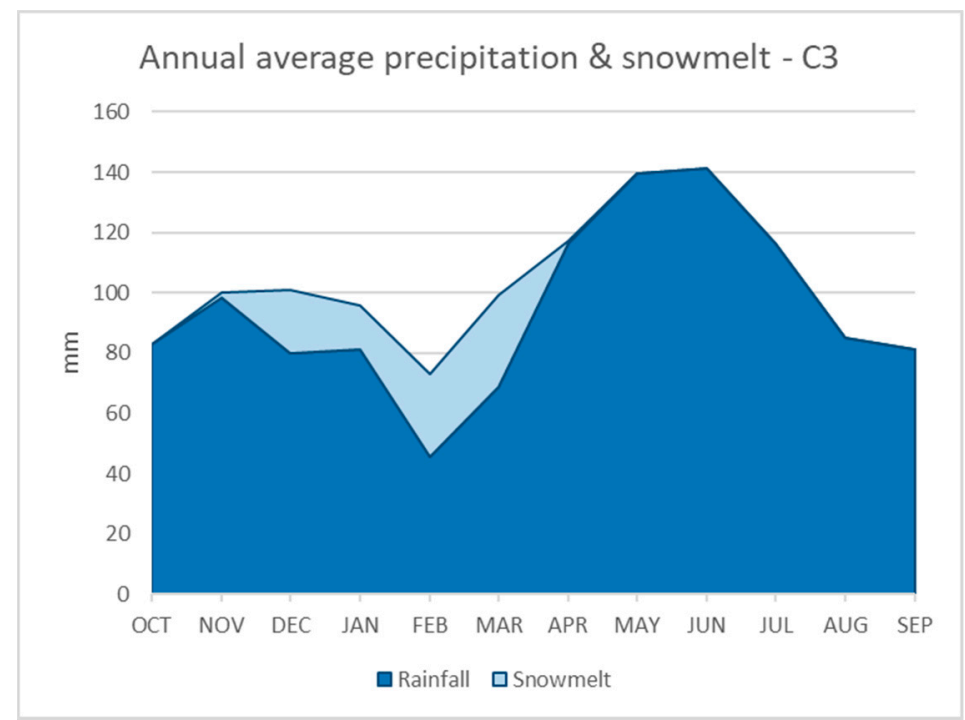

Figure 7. Annual average precipitation and snowmelt (in $\mathrm{mm}$ ) for the three configuration periods.

\subsection{Water Balance}

Analyzing the water balance components on monthly basis, we observed for the precipitation more humid conditions occurring after January, while in actual evapotranspiration marginal increase is presented mainly during the summer months as shown in Figure $8 \mathrm{~b}$. Consequently, surface runoff and water yield shown a relevant increase throughout the year from 274 to $429 \mathrm{~mm}$ and from 369 to $556 \mathrm{~mm}$, respectively. In more detail the spatial patterns of key water balance components are presented in Figure 8.

By the completion of the calibration phase, water balance components ratios were extracted from the SWAT results' databases, in annual average terms as shown in the following Table 5. Precipitation is used as the main hydrological cycle component when elaborating these ratios since it is the main water input in the SWAT model. We observed that annual average precipitation has been increased by $20 \%$ between $C_{1}$ and $C_{3}$ periods while actual evapotranspiration remained marginally stable for the same period. This resulted that between the $\mathrm{C} 1-\mathrm{C} 3$ periods we had an increase in effective precipitation from $365 \mathrm{~mm}$ up to $589 \mathrm{~mm}$ on average. Moreover, the increase in the average monthly precipitation had as a result an increase in surface runoff and total flow (summary of surface runoff, lateral flow, and groundwater return to the streams).

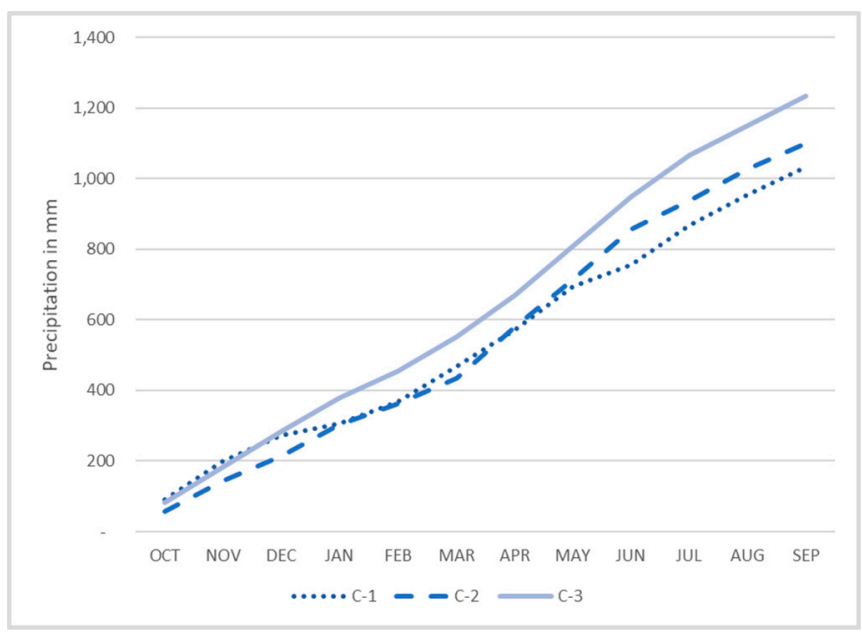

(a)

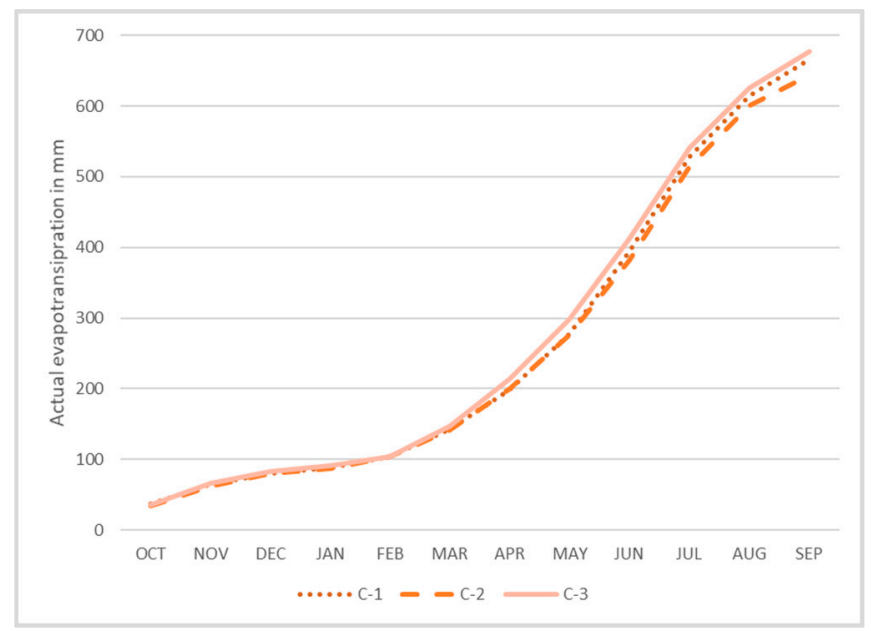

(b)

Figure 8. Cont. 


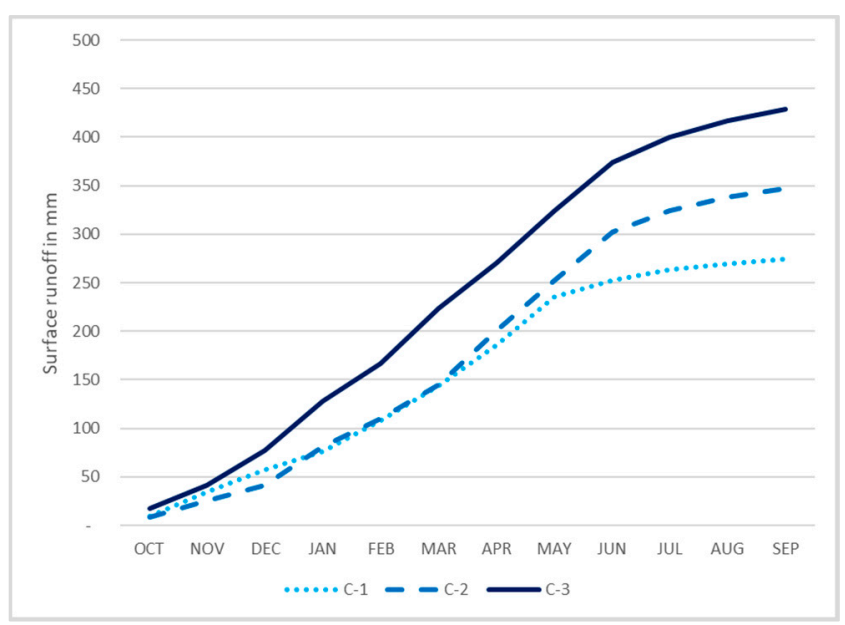

(c)

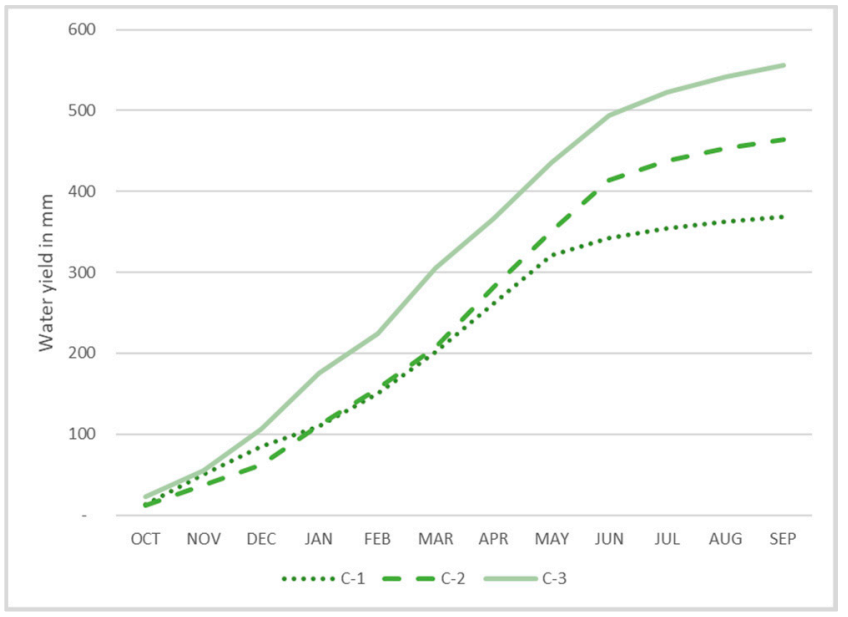

(d)

Figure 8. Cumulative water balance monthly components, on water year basis, per configuration period for (a) precipitation, (b) actual evapotranspiration, (c) surface runoff, and (d) produced water yield. All numbers are in $\mathrm{mm}$.

Table 5. Annual average water balance ratios among different hydrological cycle parameters based on SWAT outputs for all configuration periods.

\begin{tabular}{cccc}
\hline Water Balance Components Ratios & $\mathbf{C}_{\mathbf{1}}$ & $\mathbf{C}_{\mathbf{2}}$ & $\mathbf{C}_{\mathbf{3}}$ \\
\hline Streamflow/Precipitation & $27 \%$ & $31 \%$ & $35 \%$ \\
Baseflow/Total flow & $39 \%$ & $41 \%$ & $28 \%$ \\
Surface runoff/Total flow & $61 \%$ & $59 \%$ & $72 \%$ \\
Percolation/Precipitation & $11 \%$ & $13 \%$ & $11 \%$ \\
Deep recharge/Precipitation & $2 \%$ & $1 \%$ & $1 \%$ \\
Evapotranspiration/Precipitation & $64 \%$ & $58 \%$ & $54 \%$ \\
\hline
\end{tabular}

\section{Discussion}

\subsection{Model Performance}

The purpose of this hydrological modeling study was to assess the streamflow status and indirect related streamflow parameters for a long period of time in an agricultural intensive watershed. The extensive data collection system existing in the study area for weather, streamflow, water use, and agricultural practices covering the period from 1980 until 2015 and provided the necessary data inputs for a SWAT model setup. The integration of all the model inputs, have spatially explicit characteristics which were important on the design of the model evaluation. To succeed this, the period of the assessment has been split into three configuration periods where the weather, land cover, and water use data where adequately representative to conduct the calibration and validation phases of the model. Moreover, the three calibration and validation places have been selected in monitoring sites where streamflow data were available for all the period and represented in a balanced way the characteristics of their upstream draining areas. The calibration periods had a range from seven (for $\mathrm{C} 1$ and $\mathrm{C} 2$ ) up to nine years (for $\mathrm{C} 3$ ) where a three-year warm up period has been used for each one of them. The streamflow sensitive parameters have been optimized via the use the sensitivity analysis algorithm SUFI-2 of SWAT-CUP software.

The calibration results for all the monitoring sites have been improved for all the three evaluation criteria selected: $\mathrm{R}^{2}$, NSE, and PBIAS. In the first and second configuration periods the PBIAS for Sugar Creek are $13.5 \%$ and $15.3 \%$ respectively indicated underestimation of streamflow in the site. This might be a result of marginally increased losses mechanisms not releasing water in the main reach downstream to the calibration site. Other than this, the calibration performed on good and very good basis, regarding the PBIAS indicator for all monitoring sites since it has been calculated within the range of $\pm 3-10 \%$. For NSE only the Sugar Creek station, for the C1 period presented satisfactory calibration results 
with a value of 0.60 (satisfactory range $0.55-0.70$ ) which was expected as PBIAS already identified streamflow underestimation as already described. For the rest of the stations and configuration periods calibration's scores were very high and above 0.85 which is the threshold for very good hydrological simulations.

The validation phase of the model is the necessary process which verifies that the calibrated model can adequately perform for a period which was not initially used during the calibration of its parameters. The values of PBIAS in the two basins upstream of Sugar Creek (33\%) and Flatrock (14\%), indicate underestimation of streamflow in C1, while for the $\mathrm{C} 2$ and $\mathrm{C} 3$ periods, Flatrock indicated overestimation ( $-40 \%$ and $-13.4 \%$ respectively). This implies that despite the fact detailed tile drainage data and tillage practices have been integrated in the model setup, more detailed exploration is required to improve the model output within satisfactory levels. This might be a result of a change in agricultural practices followed, construction or change of operation of small water regulation infrastructure. An additional calibration point upstream of Flatrock, might support better model performance for the whole upstream subbasin. In the C3 period though, PBIAS calculated within the satisfactory values range. Considering NSE indicator, the model performed at least satisfactory at all monitoring sites.

As an additional measure of evaluation of the long period simulation in our study, we assessed the model outputs for low and high flow seasons as presented in Table 4 . For the low flow seasons and according to NSE indicator, the model performs good for the upstream basins of Sugar Creek and Flatrock, while for the downstream Columbus basin and the Seymour outlet the model performs very well at 0.84 and 0.93 NSE values respectively. The model presents satisfactory and good results for PBIAS values where Flatrock indicates marginal underestimation of the streamflow, while the rest of the three stations show higher (Sugar Creek 14\%) or within the good evaluation overestimation values (Columbus and Seymour at $4 \%$ ). For the high flow season, the model simulation presents very good performance according to NSE indicator as at all monitoring sites the values area above 0.87 and very good level of streamflow magnitude overestimation from $2 \%$ at Flatrock up to $8 \%$ in the Seymour outlet.

The Pearson correlation coefficient $\mathrm{R}^{2}$, even though it is a sensitive indicator in cases where high/low values are met, presented high level of collinearity between modeled and observed values for both the dry and wet flow seasons. The overall model validation results, indicate a progressively improving model predictability for streamflow from $\mathrm{C} 1$ to C3 configuration periods, for high flow season and from upstream to downstream locations indicating that all intermediate calibration steps at the upstream regions play a significant accumulating role for this very good model performance score at the Seymour outlet.

\subsection{Land Cover Dynamics in the Sub-Basins}

SWAT provides model outcomes in analytical database format where detailed data exports can support to further assess key outcomes of the simulations conducted. After exploring the results, we selected the four most critical water balance parameters to explore the spatial patterns of their development during the configuration periods. These parameters are the precipitation, actual evapotranspiration, surface runoff, and percolation (groundwater recharge to shallow aquifers). The spatial assessment has been conducted in terms of the areas upstream of the four calibration points as shown in Figures 9 and 10. The assessment of the water balance components is cross studied with the overall land use status for agricultural use (AGRI), pastures/hay (PAST), urbanized areas (URBAN), and forest (FOREST) as shown below. In all the four upstream areas a decreasing trend is observed in pasture/hay areas in favor of urbanization and forest expansion. Urbanization is a key parameter in altering the hydrological regime despite the fact that peri urban and independent forests within the areas presented a respective increase [98]. 


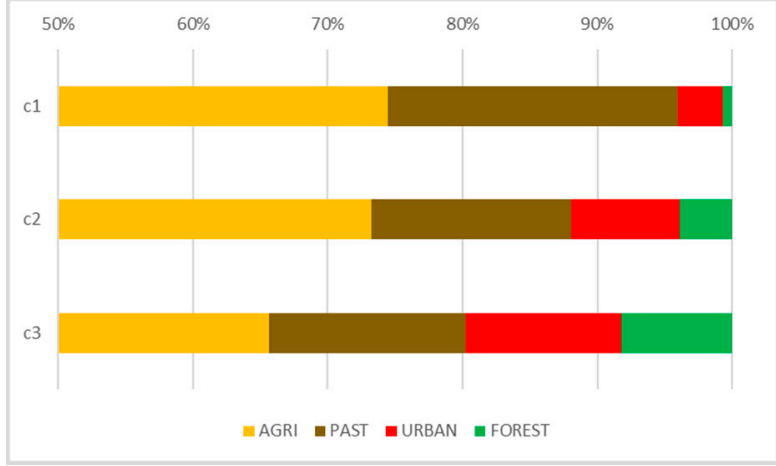

(a)

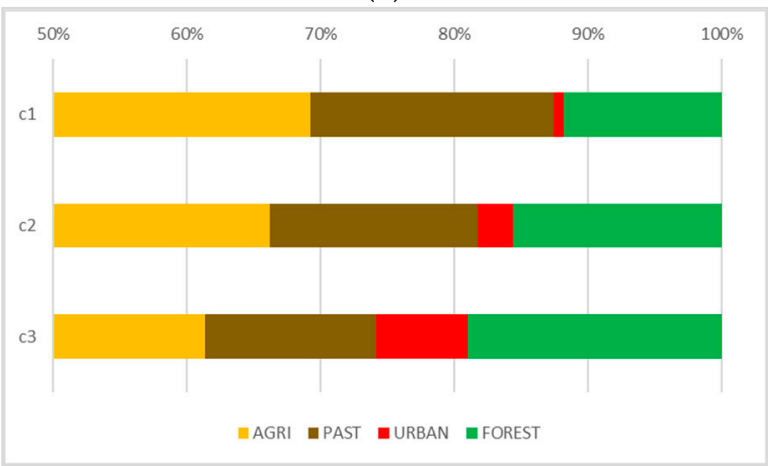

(c)

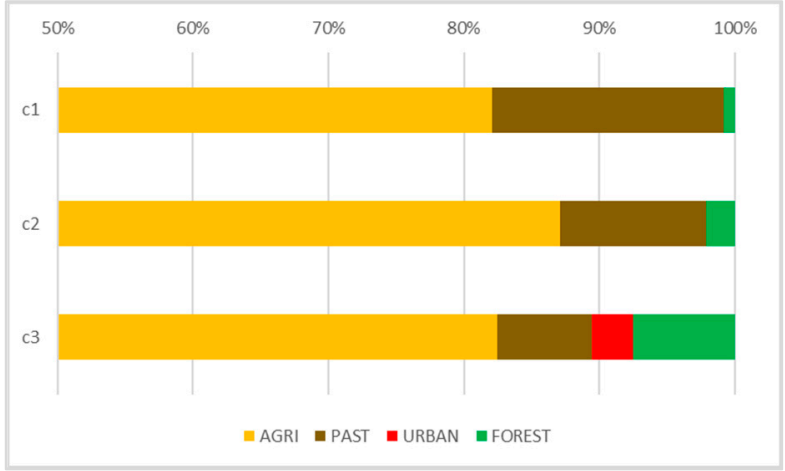

(b)

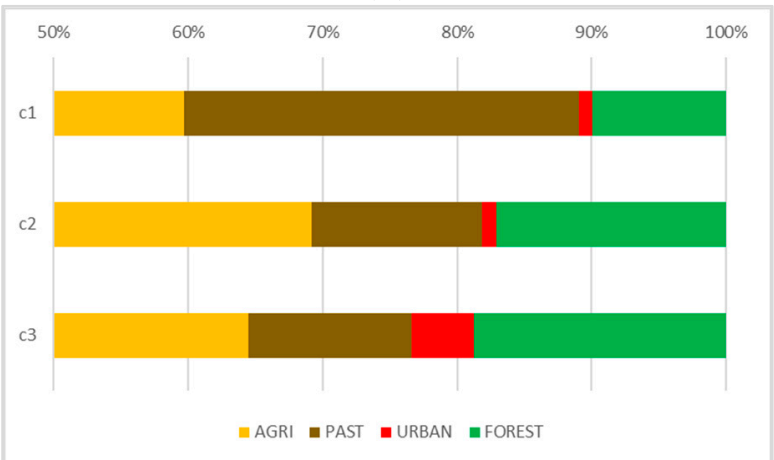

(d)

Figure 9. Land cover dynamics in the four upstream areas for (a) Sugar Creek, (b) Flatrock, (c) Columbus, and (d) Seymour outlet.

\subsection{Precipitation-Actual Evapotranspiration}

The amount of precipitation has been uniformly increased in all the four upstream regions where less increase has been observed in the headwaters of Columbus and in the intermediate zones of the river in both Columbus and Flatrock regions. While precipitation increased throughout the state, some places experienced larger increases than others with the southern and west-central regions of the state observed the largest increases [99-101].

Actual evapotranspiration did not have any major change in the UEFWR, except in upstream of Columbus and within the major two out of three tributaries. The significant reduction of pastures areas in both Flatrock and Seymour is one of the reasons affecting the regional marginal reduction of the evapotranspiration from natural vegetated areas.

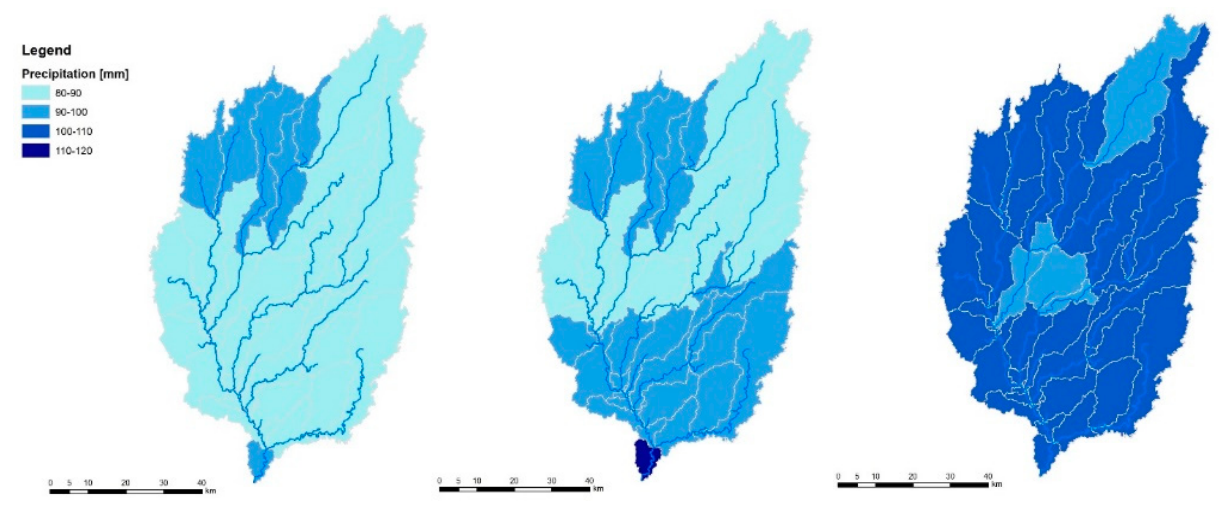

Figure 10. Cont. 


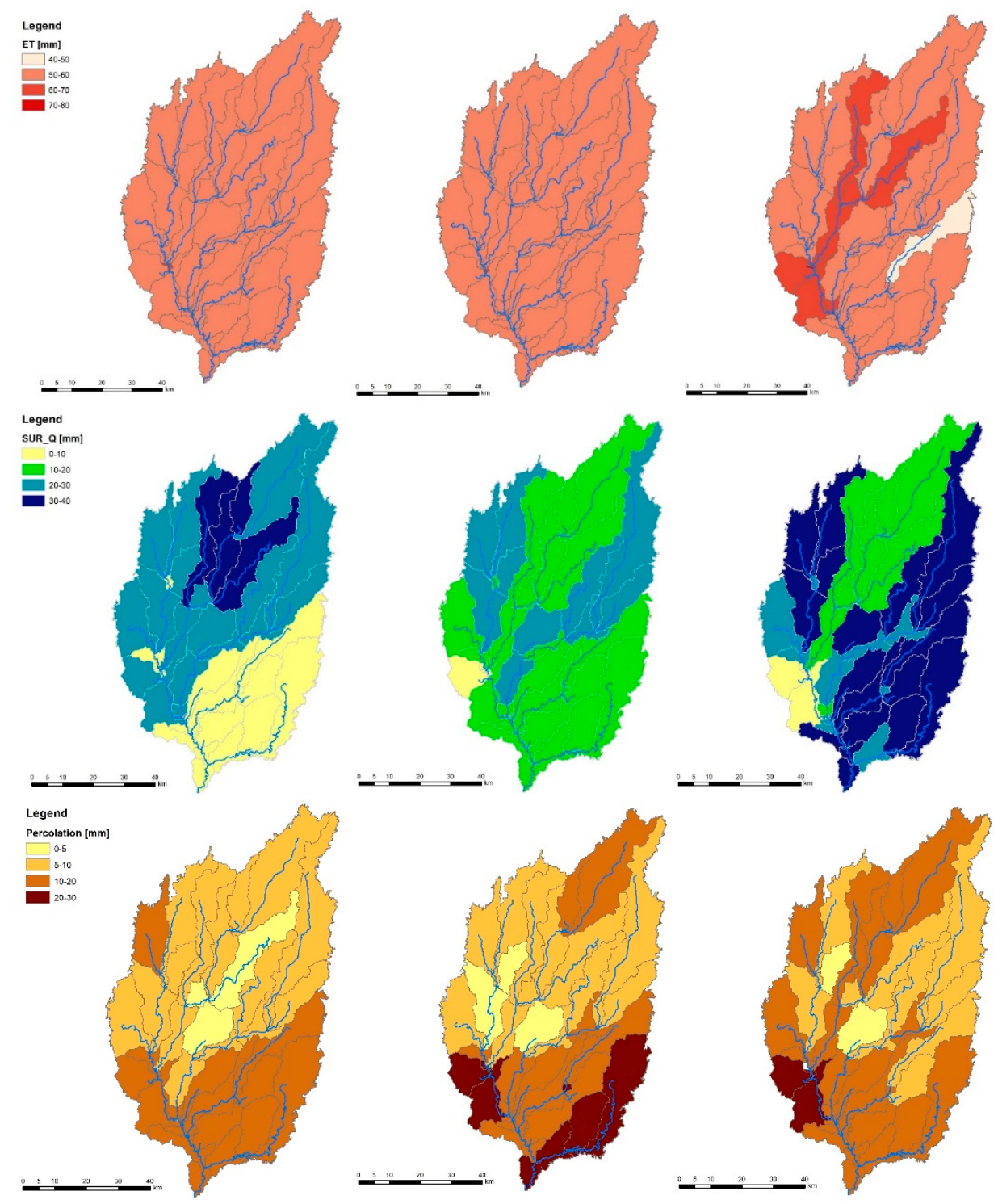

Figure 10. Precipitation, actual evapotranspiration, surface runoff, and percolation maps at subbasin level for each of the configuration periods $\left(C_{1}, C_{2}\right.$, and $\left.C_{3}\right)$ from left to right. All the values presented are in $\mathrm{mm}$.

\subsection{Surface Runoff-Percolation-Tile Drainage}

As a result of the overall increase in precipitation, this consequently affected the surface runoff throughout the basins and more specifically the upstream areas of Flatrock and Seymour. As the agricultural areas in Seymour have been increased, more subsurface drainage networks have been installed since the latest available data indicate at least a $2773 \mathrm{~km}^{2}$ increase in land drained by tile, rising to a total of $27 \%$ at state level $\left(26,000 \mathrm{~km}^{2}\right)[102,103]$. The dipole between surface runoff and percolation seem to interact in opposite directions due to the existence of extended tile drainage in the agricultural parts of the study area. In detail, percolation affected by the existence of crops cultivation rather than surface runoff which is controlled by forest and urban expansion. In Sugar Creek land cover change dynamics are affected more by the extensive urban expansion, with the headwater regions present a slight increase in percolation rates. For Flatrock, the high level of croplands ( $80 \%)$ govern the water balance especially in the downstream regions close to Columbus keeping percolation/precipitation rates within the range of $6-8 \%$, while less than $10 \%$ increase of forests positively affect the surface runoff. 
Upstream of Columbus, the reduction of agricultural and pasture areas effectively increased the percolation rates, which resulted in reducing the surface runoff/precipitation rates. More detailed results for all the stations and configuration periods are presented in Figure 11 below.

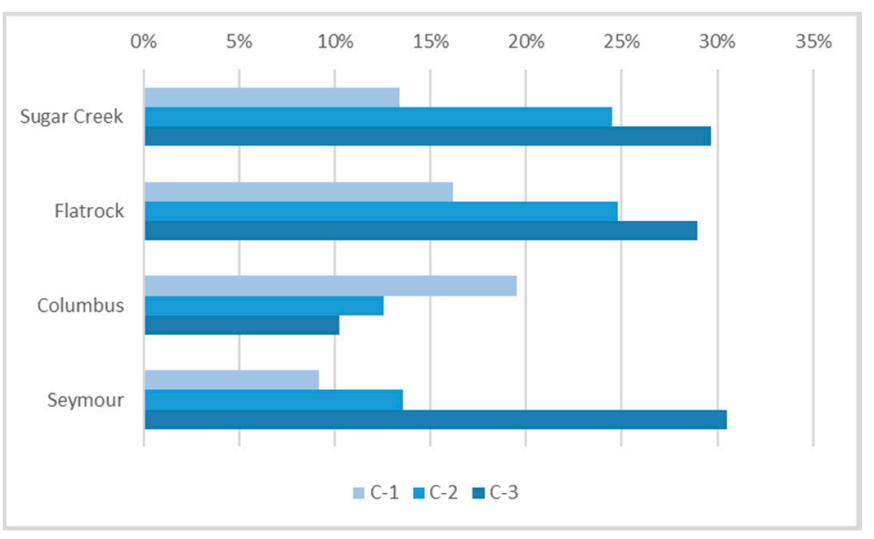

(a)

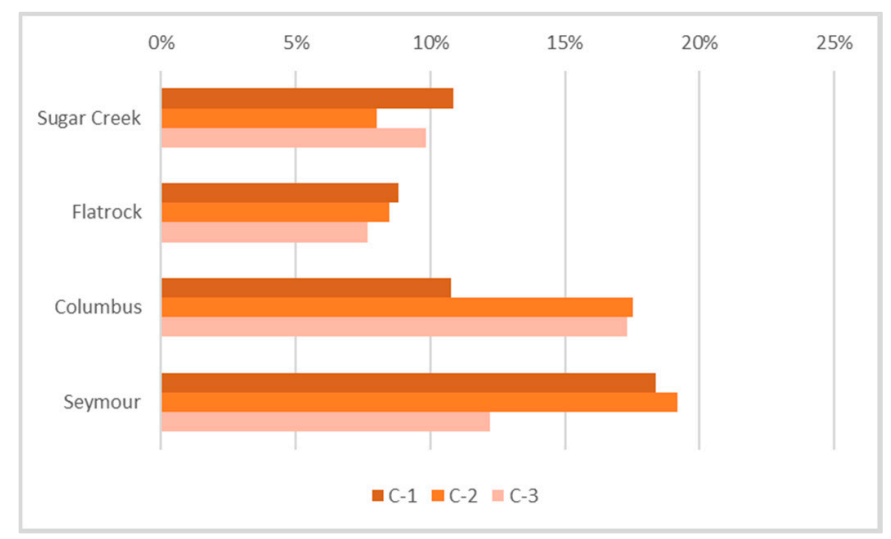

(b)

Figure 11. Water balance ratios for each of the upstream drainage areas and per configuration period for (a) surface runoff/precipitation and (b) percolation/precipitation.

\section{Conclusions}

In this study, we examined the spatial variability of the main water balance components in an intensively agricultural area in the headwaters of Upper East Fork White River in Indiana, USA. The assessment time range has been divided in three configuration periods to adequately capture potential weather (precipitation and temperature) and land cover changes during the years from 1980 to 2015; following urbanization trends against pastures and peri-urban agricultural areas. Extensive data collection was necessary to provide the best possible data input for a SWAT model set up for the simulation. In order to optimize the data outputs, a spatial calibration approach has been implemented in four gauging sites, by using the auto calibration SUFI-2 algorithm for eight sensitive land cover, soil, and groundwater parameters, where the results were very satisfactory for all the configuration periods and calibration points.

The model evaluation criteria for both calibration $\left(R^{2}=0.90, \mathrm{NSE}=0.88, \mathrm{PBIAS}=6.50 \%\right)$ and validation periods $\left(\mathrm{R}^{2}=0.89, \mathrm{NSE}=0.88, \mathrm{PBIAS}=-2.8 \%\right)$ at Seymour outlet, indicate a strong correlation and goodness of fit for the most recent configuration period as well as for the two initial ones, while this very good performance in the outlet is being sustained when evaluating both dry $\left(R^{2}=0.88\right.$, NSE $=0.93$, PBIAS $\left.=4 \%\right)$ and wet $\left(R^{2}=0.94\right.$, NSE $=0.94$, PBIAS $=8 \%$ ) seasons.

It was confirmed that in areas with intensified agricultural development, an activity which heavily disturbs the land phase of the hydrological cycle, it is important and critical for hydrological models to integrate data input such water use and relevant agricultural management practices. Those proved to considerably affect the regional hydrological balance as indicated while using precipitation ratios with surface runoff and percolation. The practice of easy-to-use model outputs expressed as ratios can provide a brief description of the water balance dynamics in the study area, allowing proper adjustment of the hydrological model parameters.

The results of this study can be generalized to other watersheds with extensive agricultural land cover and crop synthesis to the extent that supportive information is available on the agricultural practices applied in them such as tile drainage, tillage as well as the soil characteristics of plainlands. They can ideally provide insights for further long-term assessments and improvements in the hydrological cycle representation via the SWAT model, in a way that will promote environmental sustainability (scenario building) while ensuring socioeconomic stability and production of critical crops. 
Author Contributions: Conceptualization, G.B. and E.B.; Methodology, G.B.; Software, G.B.; Validation, G.B.; Formal analysis, G.B.; Investigation, G.B.; Resources, G.B. and E.B.; Data curation, G.B.; Writing-original draft preparation, G.B. and E.B.; Writing—review and editing, G.B.; Visualization, G.B.; Supervision, E.B. Both authors have read and agreed to the published version of the manuscript.

Funding: This research received no external funding.

Conflicts of Interest: The authors declare no conflict of interest.

\section{References}

1. United Nations. World Population Prospects 2019; Nations United: San Francisco, CA, USA, 2019; ISBN 9789211483161.

2. FAO Aquastat-Water Use Thematic Assessment. Available online: http://www.fao.org/aquastat/en/overview/methodology/ water-use (accessed on 1 July 2021).

3. Dieter, C.A.; Maupin, M.A.; Caldwell, R.R.; Harris, M.A.; Ivahnenko, T.I.; Lovelace, J.K.; Barber, N.L.; Linsey, K. Estimated Use of Water in the United States in 2015; U.S. Geological Survey: Reston, VA, USA, 2018.

4. NCEI U.S. Agricultural Belts. Available online: https://www.ncdc.noaa.gov/monitoring-references/maps/us-ag-belts.php\# winter-wheat (accessed on 1 July 2021)

5. Socolar, Y.; Goldstein, B.R.; De Valpine, P.; Bowles, T.M. Biophysical and policy factors predict simplified crop rotations in the US Midwest. Environ. Res. Lett. 2021, 16, 054045. [CrossRef]

6. ISDA: About Indiana Agriculture. Available online: https://www.in.gov/isda/about/about-indiana-agriculture/ (accessed on 1 July 2021).

7. USDA. Census of Agriculture. Available online: https://www.nass.usda.gov/AgCensus/index.php (accessed on 1 July 2021).

8. David, M.B.; Drinkwater, L.E.; McIsaac, G.F. Sources of Nitrate Yields in the Mississippi River Basin. J. Environ. Qual. 2010, 39, 1657-1667. [CrossRef]

9. Kladivko, E.J.; Van Scoyoc, G.E.; Monke, E.J.; Oates, K.M.; Pask, W. Pesticide and Nutrient Movement into Subsurface Tile Drains on a Silt Loam Soil in Indiana. J. Environ. Qual. 1991, 20, 264-270. [CrossRef]

10. Valayamkunnath, P.; Barlage, M.; Chen, F.; Gochis, D.J.; Franz, K.J. Mapping of 30-meter resolution tile-drained croplands using a geospatial modeling approach. Sci. Data 2020, 7, 1-10. [CrossRef]

11. Elosegi, A.; Díez, J.; Mutz, M. Effects of hydromorphological integrity on biodiversity and functioning of river ecosystems. Hydrobiologia 2010, 657, 199-215. [CrossRef]

12. Valle Junior, R.F.; Varandas, S.G.P.; Pacheco, F.A.L.; Pereira, V.R.; Santos, C.F.; Cortes, R.M.V.; Sanches Fernandes, L.F. Impacts of land use conflicts on riverine ecosystems. Land Use Policy 2015, 43, 48-62. [CrossRef]

13. Quintas-Soriano, C.; Castro, A.J.; Castro, H.; García-Llorente, M. Impacts of land use change on ecosystem services and implications for human well-being in Spanish drylands. Land Use Policy 2016, 54, 534-548. [CrossRef]

14. Ju, X.T.; Xing, G.X.; Chen, X.P.; Zhang, S.L.; Zhang, L.J.; Liu, X.J.; Cui, Z.L.; Yin, B.; Christie, P.; Zhu, Z.L.; et al. Reducing environmental risk by improving $\mathrm{N}$ management in intensive Chinese agricultural systems. Proc. Natl. Acad. Sci. USA 2009, 106, 8077. [CrossRef] [PubMed]

15. Theodoropoulos, C.; Iliopoulou-Georgudaki, J. Response of biota to land use changes and water quality degradation in two medium-sized river basins in southwestern Greece. Ecol. Indic. 2010, 10, 1231-1238. [CrossRef]

16. Alexander, R.B.; Smith, R.A.; Schwarz, G.E. Effect of stream channel size on the delivery of nitrogen to the Gulf of Mexico. Nature 2000, 403, 758-761. [CrossRef] [PubMed]

17. Faust, D.R.; Kröger, R.; Moore, M.T.; Rush, S.A. Management Practices Used in Agricultural Drainage Ditches to Reduce Gulf of Mexico Hypoxia. Bull. Environ. Contam. Toxicol. 2018, 100, 32-40. [CrossRef] [PubMed]

18. Turner, R.E.; Rabalais, N.N.; Justic, D. Gulf of Mexico hypoxia: Alternate states and a legacy. Environ. Sci. Technol. 2008, 42, 2323-2327. [CrossRef] [PubMed]

19. Whittaker, G.; Barnhart, B.L.; Srinivasan, R.; Arnold, J.G. Cost of areal reduction of gulf hypoxia through agricultural practice. Sci. Total Environ. 2015, 505, 149-153. [CrossRef] [PubMed]

20. Worku, T.; Khare, D.; Tripathi, S.K. Modeling runoff-sediment response to land use/land cover changes using integrated GIS and SWAT model in the Beressa watershed. Environ. Earth Sci. 2017, 76, 1-14. [CrossRef]

21. Myers, D.N.; Metzker, K.D.; Davis, S. Status and trends in suspended-sediment discharges, soil erosion, and conservation tillage in the Maumee River basin-Ohio, Michigan, and Indiana. In Water-Resources Investigation Report; U.S. Geological Survey: Reston, VA, USA, 2000.

22. Meshesha, T.W.; Wang, J.; Melaku, N.D. Modelling spatiotemporal patterns of water quality and its impacts on aquatic ecosystem in the cold climate region of Alberta, Canada. J. Hydrol. 2020, 587, 124952. [CrossRef]

23. Mueller, N.D.; Gerber, J.S.; Johnston, M.; Ray, D.K.; Ramankutty, N.; Foley, J.A. Closing yield gaps through nutrient and water management. Nature 2012, 490, 254-257. [CrossRef] [PubMed]

24. Van Loon, A.F.; Rangecroft, S.; Coxon, G.; Naranjo, J.A.B.; Van Ogtrop, F.; Van Lanen, H.A.J. Using paired catchments to quantify the human influence on hydrological droughts. Hydrol. Earth Syst. Sci. 2019, 23, 1725-1739. [CrossRef]

25. Aryal, Y.; Zhu, J. Effect of watershed disturbance on seasonal hydrological drought: An improved double mass curve (IDMC) technique. J. Hydrol. 2020, 585, 124746. [CrossRef] 
26. Devia, G.K.; Ganasri, B.P.; Dwarakish, G.S. A Review on Hydrological Models. Aquat. Procedia 2015, 4, 1001-1007. [CrossRef]

27. Kiprotich, P.; Wei, X.; Zhang, Z.; Ngigi, T.; Qiu, F.; Wang, L. Assessing the impact of land use and climate change on surface runoff response using gridded observations and swat+. Hydrology 2021, 8, 48. [CrossRef]

28. Rajib, A.; Kim, I.L.; Golden, H.E.; Lane, C.R.; Kumar, S.V.; Yu, Z.; Jeyalakshmi, S. Watershed modeling with remotely sensed big data: MODIS leaf area index improves hydrology and water quality predictions. Remote Sens. 2020, 12, 2148. [CrossRef]

29. Rajib, M.A.; Merwade, V.; Yu, Z. Multi-objective calibration of a hydrologic model using spatially distributed remotely sensed/insitu soil moisture. J. Hydrol. 2016, 536, 192-207. [CrossRef]

30. Yifru, B.A.; Mitiku, D.B.; Tolera, M.B.; Chang, S.W.; Chung, I.M. Groundwater Potential Mapping Using SWAT and GIS-Based Multi-Criteria Decision Analysis. KSCE J. Civ. Eng. 2020, 24, 2546-2559. [CrossRef]

31. Liu, Y.; Wang, R.; Guo, T.; Engel, B.A.; Flanagan, D.C.; Lee, J.G.; Li, S.; Pijanowski, B.C.; Collingsworth, P.D.; Wallace, C.W. Evaluating efficiencies and cost-effectiveness of best management practices in improving agricultural water quality using integrated SWAT and cost evaluation tool. J. Hydrol. 2019, 577, 123965. [CrossRef]

32. Oh, H.C.; Shimizu, Y.; Kim, S.K. Effect Analysis Regarding Different Scenarios to Improve Water Quality of the Lake Paldang Basin in Korea. KSCE J. Civ. Eng. 2018, 22, 3246-3253. [CrossRef]

33. Moriasi, D.N.; Starks, P.J.; Steiner, J.L.; Zhang, X.C.; Garbrecht, J.D.; Glasgow, S. An overview of research into conservation practice effects on soil and water resources in the Upper Washita Basin, Oklahoma, United States. J. Soil Water Conserv. 2020, 75, 330-339. [CrossRef]

34. Carvalho-Santos, C.; Marcos, B.; Nunes, J.P.; Regos, A.; Palazzi, E.; Terzago, S.; Monteiro, A.T.; Honrado, J.P. Hydrological impacts of large fires and future climate: Modeling approach supported by satellite data. Remote Sens. 2019, 11, 2832. [CrossRef]

35. Pokhrel, Y.; Burbano, M.; Roush, J.; Kang, H.; Sridhar, V.; Hyndman, D.W. A review of the integrated effects of changing climate, land use, and dams on Mekong river hydrology. Water 2018, 10, 266. [CrossRef]

36. Wang, H.; Stephenson, S.R.; Qu, S. Quantifying the relationship between streamflow and climate change in a small basin under future scenarios. Ecol. Indic. 2020, 113, 106251. [CrossRef]

37. White, M.J.; Beiger, K.; Gambone, M.; Haney, E.; Arnold, J.; Gao, J. Development of a hydrologic connectivity dataset for SWAT assessments in the US. Water 2017, 9, 892. [CrossRef]

38. Meng, X.; Wang, H.; Shi, C.; Wu, Y.; Ji, X. Establishment and evaluation of the China meteorological assimilation driving datasets for the SWAT model (CMADS). Water 2018, 10, 1555. [CrossRef]

39. Abbaspour, K.C.; Vaghefi, S.A.; Yang, H.; Srinivasan, R. Global soil, landuse, evapotranspiration, historical and future weather databases for SWAT Applications. Sci. Data 2019, 6, 1-11. [CrossRef]

40. Rajib, A.; Merwade, V. Hydrologic response to future land use change in the Upper Mississippi River Basin by the end of 21st century. Hydrol. Process. 2017, 31, 3645-3661. [CrossRef]

41. Parshotam, A. An evaluation of Climate Forecast System Reanalysis (CFSR) data for use in models that require meteorological weather station data in New Zealand. Agron. N. Z. 2019, 49, 51-62.

42. Ali, Y.S.A.; Crosato, A.; Mohamed, Y.A.; Abdalla, S.H.; Wright, N.G. Sediment balances in the Blue Nile River Basin. Int. J. Sediment Res. 2014, 29, 316-328. [CrossRef]

43. Haimann, M.; Liedermann, M.; Lalk, P.; Habersack, H. An integrated suspended sediment transport monitoring and analysis concept. Int. J. Sediment Res. 2014, 29, 135-148. [CrossRef]

44. Yen, H.; White, M.J.; Jeong, J.; Arabi, M.; Arnold, J.G. Evaluation of alternative surface runoff accounting procedures using the SWAT model. Int. J. Agric. Biol. Eng. 2015, 8, 54-68. [CrossRef]

45. Freund, E.R.; Abbaspour, K.C.; Lehmann, A. Water resources of the Black Sea Catchment under future climate and landuse change projections. Water 2017, 9, 598. [CrossRef]

46. Farjad, B.; Gupta, A.; Razavi, S.; Faramarzi, M.; Marceau, D.J. An integrated modelling system to predict hydrological processes under climate and land-use/cover change scenarios. Water 2017, 9, 767. [CrossRef]

47. Arnold, J.G.; White, M.J.; Allen, P.M.; Gassman, P.W.; Bieger, K. Conceptual Framework of Connectivity for a National Agroecosystem Model Based on Transport Processes and Management Practices. J. Am. Water Resour. Assoc. 2021, 57, 154-169. [CrossRef]

48. Singh, J.; Knapp, H.V.; Arnold, J.G.; Demissie, M. Hydrological modeling of the Iroquois River watershed using HSPF and SWAT. J. Am. Water Resour. Assoc. 2005, 41, 343-360. [CrossRef]

49. Tan, M.L.; Gassman, P.W.; Yang, X.; Haywood, J. A review of SWAT applications, performance and future needs for simulation of hydro-climatic extremes. Adv. Water Resour. 2020, 143, 103662. [CrossRef]

50. Fidelis, T.; Roebeling, P. Water resources and land use planning systems in Portugal—Exploring better synergies through Ria de Aveiro. Land Use Policy 2014, 39, 84-95. [CrossRef]

51. Hubbart, J.A.; Kellner, E.; Zeiger, S.J. A case-study application of the experimental watershed study design to advance adaptive management of contemporary watersheds. Water 2019, 11, 2355. [CrossRef]

52. UNSD. System of Environmental-Economic Accounting, Central Framework; ST/ESA/STAT/Ser.F/109; UNSD: New York, NY, USA, 2012.

53. Zal, N.; Bariamis, G.; Zachos, A.; Baltas, E.; Mimikou, M. Use of Freshwater Resources in Europe 2002-2014; EEA: København, Copenhagen, 2017.

54. Bariamis, G.; Paschos, G.; Baltas, E. Land Accounts in the River Basin Districts of Greece. Environ. Process. 2018, 5. [CrossRef] 
55. Bagstad, K.J.; Ancona, Z.H.; Hass, J.; Glynn, P.D.; Wentland, S.; Vardon, M.; Fay, J. Integrating physical and economic data into experimental water accounts for the United States: Lessons and opportunities. Ecosyst. Serv. 2020, 45, 101182. [CrossRef]

56. USGS Watershed Boundary Dataset. Available online: https://www.usgs.gov/core-science-systems/ngp/nationalhydrography / watershed-boundary-dataset?qt-science_support_page_related_con=4\#qt-science_support_page_related_con (accessed on 1 July 2021).

57. NASA Shuttle Radar Topography Mission. Available online: https://www2.jpl.nasa.gov/srtm/cbanddataproducts.html (accessed on 1 July 2021).

58. USDA United States General Soil Map (STATSGO2). Available online: https://data.nal.usda.gov/dataset/united-states-generalsoil-map-statsgo2 (accessed on 1 July 2021).

59. USDA Description of STATSGO2 Database I NRCS Soils. Available online: https://www.nrcs.usda.gov/wps/portal/nrcs/ detail/soils/survey/geo/?cid=nrcs142p2_053629 (accessed on 1 July 2021).

60. NOAA. 1991-2020 Climate Normals Indiana; NOAA: Washington, DC, USA, 2021.

61. USGS National Climatic Data Center (NCDC). Available online: https:/ / www.ncdc.noaa.gov/cdo-web/datasets (accessed on 1 July 2021).

62. Boryan, C.; Yang, Z.; Mueller, R.; Craig, M. Monitoring US agriculture: The US department of agriculture, national agricultural statistics service, cropland data layer program. Geocarto Int. 2011, 26, 341-358. [CrossRef]

63. USGS Indiana National Land Cover Dataset 1992. Available online: https://maps.indiana.edu/previewMaps/Environment/ Land_Cover_1992.html (accessed on 18 July 2021).

64. Han, W.; Yang, Z.; Di, L.; Mueller, R. CropScape: A Web service based application for exploring and disseminating US conterminous geospatial cropland data products for decision support. Comput. Electron. Agric. 2012, 84, 111-123. [CrossRef]

65. Wickham, J.D.; Stehman, S.V.; Smith, J.H.; Yang, L. Thematic accuracy of the 1992 National Land-Cover Data for the western United States. Remote Sens. Environ. 2004, 91, 452-468. [CrossRef]

66. Wickham, J.D.; Stehman, S.V.; Fry, J.A.; Smith, J.H.; Homer, C.G. Thematic accuracy of the NLCD 2001 land cover for the conterminous United States. Remote Sens. Environ. 2010, 114, 1286-1296. [CrossRef]

67. USDA CropScape-NASS CDL Program. Available online: https:/ / nassgeodata.gmu.edu/CropScape/ (accessed on 1 July 2021).

68. Arnold, J.G.; Srinivasan, R.; Muttiah, R.S.; Williams, J.R. Large area hydrologic modelling and assessment Part I: Model development. J. Am. Water Resour. Assoc. 1998, 34, 73-89. [CrossRef]

69. Neitsch, S.; Arnold, J.; Kiniry, J.; Williams, J. Soil \& Water Assessment Tool Theoretical Documentation Version 2009. Texas Water Resour. Inst. 2011, 1-647. [CrossRef]

70. Arnold, J.G.; Allen, P.M.; Bernhardt, G. A comprehensive surface-groundwater flow model. J. Hydrol. 1993, 142, 47-69. [CrossRef]

71. Arnold, J.G.; Williams, J.R.; Maidment, D.R. Continuous-Time Water and Sediment-Routing Model for Large Basins. J. Hydraul. Eng. 1995, 121, 171-183. [CrossRef]

72. Srinivasan, R.; Ramanarayanan, T.; Arnold, J.G.; Bednarz, S. Large area hydrologicl modelling and assessment Part II: Model application. J. Am. Water Resour. Assoc. 1998, 34, 91-101. [CrossRef]

73. SWAT ArcSWAT Interface Version 24 October 2012. Available online: https://swat.tamu.edu/software/arcswat/ (accessed on 1 July 2021).

74. USDA NASS. Indiana Corn County Estimates 2019; USDA NASS: Washington, DC, USA, 2020; Volume 48823.

75. USDA NASS. Indiana Soybeans County Estimates 2019; NASS: Washington, DC, USA, 2020; Volume 48823.

76. Panagopoulos, Y.; Gassman, P.W.; Jha, M.K.; Kling, C.L.; Campbell, T.; Srinivasan, R.; White, M.; Arnold, J.G. A refined regional modeling approach for the Corn Belt-Experiences and recommendations for large-scale integrated modeling. J. Hydrol. 2015, 524, 348-366. [CrossRef]

77. Schilling, K.E.; Jha, M.K.; Zhang, Y.-K.; Gassman, P.W.; Wolter, C.F. Impact of land use and land cover change on the water balance of a large agricultural watershed: Historical effects and future directions. Water Resour. Res. 2008, 44, 1-12. [CrossRef]

78. DNR Significant Water Withdrawal Facility Data. Available online: https://www.in.gov/dnr/water/water-availability-userights/significant-water-withdrawal-facility-data/ (accessed on 1 July 2021).

79. Solley, W.B.; Chase, E.B.; Mann, W.B.I. Estimated Use of Water in the United States in 1980; U.S. Geological Survey Circular: Reston, VA, USA, 1983.

80. Solley, W.B.; Merk, C.F.; Pierce, R.R. Estimated Use of Water in the United States in 1985; U.S. Geological Survey Circular: Reston, VA, USA, 1988.

81. Solley, W.B.; Pierce, R.R.; Perlman, H.A. Estimated Use of Water in the United States in 1990; U.S. Geological Survey Circular: Reston, VA, USA, 1993.

82. Hutson, S.S.; Barber, N.L.; Kenny, J.F.; Linsey, K.S.; Lumia, D.S.; Maupin, M.A. Estimated use of water in the United States in 2000; U.S. Geological Survey Circular: Reston, VA, USA, 2004; ISBN 060797818X.

83. Kenny, J.F.; Barber, N.L.; Hutson, S.S.; Linsey, K.S.; Lovelace, J.K.; Maupin, M.A. Estimated Use of Water in the United States in 2005; U.S. Geological Survey Circular: Reston, VA, USA, 2005; Volume 1344, ISBN 9781411326002.

84. Maupin, M.A.; Kenny, J.F.; Hutson, S.S.; Lovelace, J.K.; Barber, N.L.; Linsey, K.S. Estimated Use of Water in the United States in 2010; U.S. Geological Survey Circular: Reston, VA, USA, 2010; ISBN 9781411338623.

85. Coast, G.; Catahoula, T.; Counties, G.; Counties, J.; County, W.; County, J.; County, H.; Water, T.; Board, D.; District, H.C.S. Estimated Use of Water in the United States in 1995; U.S. Geological Survey Circular: Reston, VA, USA, 1998; ISBN 060790075X. 
86. Abbaspour, K.C.; Johnson, C.A.; van Genuchten, M.T. Estimating Uncertain Flow and Transport Parameters Using a Sequential Uncertainty Fitting Procedure. Vadose Zo. J. 2004, 3, 1340-1352. [CrossRef]

87. Du, L.; Rajib, A.; Merwade, V. Large scale spatially explicit modeling of blue and green water dynamics in a temperate mid-latitude basin. J. Hydrol. 2018, 562, 84-102. [CrossRef]

88. Jang, W.S.; Engel, B.; Ryu, J. Efficient flow calibration method for accurate estimation of baseflow using a watershed scale hydrological model (SWAT). Ecol. Eng. 2018, 125, 50-67. [CrossRef]

89. Woldesenbet, T.A.; Elagib, N.A.; Ribbe, L.; Heinrich, J. Hydrological responses to land use/cover changes in the source region of the Upper Blue Nile Basin, Ethiopia. Sci. Total Environ. 2017, 575, 724-741. [CrossRef] [PubMed]

90. White, J.; Stengel, V.; Rendon, S.; Banta, J. The importance of parameterization when simulating the hydrologic response of vegetative land-cover change. Hydrol. Earth Syst. Sci. 2017, 21, 3975-3989. [CrossRef]

91. Arnold, J.G.; Moriasi, D.N.; Gassman, P.W.; Abbaspour, K.C.; White, M.J.; Srinivasan, R.; Santhi, C.; Harmel, R.D.; Van Griensven, A.; Van Liew, M.W.; et al. SWAT: Model use, calibration, and validation. Trans. ASABE 2012, 55, 1491-1508. [CrossRef]

92. Panagopoulos, Y.; Gassman, P.W.; Kling, C.L.; Cibin, R.; Chaubey, I. Water Quality Assessment of Large-scale Bioenergy Cropping Scenarios for the Upper Mississippi and Ohio-Tennessee River Basins. J. Am. Water Resour. Assoc. 2017, 53, 1355-1367. [CrossRef]

93. Abbaspour, K.C.; Vaghefi, S.A.; Srinivasan, R. A guideline for successful calibration and uncertainty analysis for soil and water assessment: A review of papers from the 2016 international SWAT conference. Water 2017, 10, 6. [CrossRef]

94. Nash, J.E.; Sutcliffe, J.V. River flow forecasting through conceptual models PART I-A discussion of principles. J. Hydrol. 1970, 10, 282-290. [CrossRef]

95. Moriasi, D.N.; Gitau, M.W.; Pai, N.; Daggupati, P. Hydrologic and water quality models: Performance measures and evaluation criteria. Trans. ASABE 2015, 58, 1763-1785. [CrossRef]

96. Moriasi, D.N.; Arnold, J.G.; Van Liew, M.W.; Bingner, R.L.; Harmel, R.D.; Veith, T.L. Model evaluation guidelines for systematic quantification of accuracy in watershed simulations. Trans. ASABE 2007, 50, 885-900. [CrossRef]

97. ASABE. Guidelines for Calibrating, Validating, and Evaluating Hydrologic and Water Quality (H/WQ) Models. Trans. ASABE 2017, 61, 1-15.

98. Aboelnour, M.; Gitau, M.W.; Engel, B.A. Hydrologic response in an urban watershed as affected by climate and land-use change. Water 2019, 11, 1603. [CrossRef]

99. Widhalm, M.; Hamlet, A.; Byun, K.; Robeson, S.; Baldwin, M.; Staten, P.; Huber, M. Indiana's Past E Future Climate: A Report from the Indiana Climate Change Impacts Assessment; Purdue Climate Change Research Center, Purdue University: West Lafayette, IN, USA, 2018; pp. 1-13. [CrossRef]

100. Gowda, P.; Steiner, J.L.; Olson, C.; Boggess, M.; Farrigan, T.; Grusak, M.A. Impacts, Risks, and Adaptation in the United Stated: Fourth National Climate Assessment, Volume II: Agriculture and Rural Communities; U.S. Global Change Research Program: Washington, DC, USA, 2018; Volume II.

101. Angel, J.R.; Swanson, C.; Boustead, B.M.; Conlon, K.; Hall, K.R.; Jorns, J.L.; Kunkel, K.E.; Lemos, M.C.; Lofgren, B.M.; Ontl, T.; et al. Midwest. Impacts, Risks, and Adaptation in the United States: The Fourth National Climate Assessment; U.S. Global Change Research Program: Washington, DC, USA, 2018; Volume II.

102. USDA. Agricultural Census; USDA: Washington, DC, USA, 2012; Volume 1, pp. 196-209.

103. USDA. Agricultural Census; USDA: Washington, DC, USA, 2017; pp. 192-205. 